\title{
Analysis of Vinylene Carbonate (VC) as Additive in Graphite/LiNi ${ }_{0.5} \mathrm{Mn}_{1.5} \mathrm{O}_{4}$ Cells
}

\author{
Daniel Pritzl,,"z Sophie Solchenbach," Morten Wetjen, and Hubert A. Gasteiger** \\ Chair for Technical Electrochemistry, Department of Chemistry and Catalysis Research Center, Technical University of \\ Munich, Munich, Germany
}

\begin{abstract}
Vinylene Carbonate (VC) is an effective electrolyte additive to produce a stable solid electrolyte interphase (SEI) on graphite anodes, increasing the capacity retention of lithium-ion cells. However, in combination with $\mathrm{LiNi}_{0.5} \mathrm{Mn}_{1.5} \mathrm{O}_{4}(\mathrm{LNMO})$ cathodes, $\mathrm{VC}$ drastically decreases cell performance. In this study we use on-line electrochemical mass spectrometry (OEMS) and electrochemical impedance spectroscopy (EIS) with a micro-reference electrode to understand the oxidative (in-)stability of VC and its effect on the interfacial resistances of both anode and cathode. We herein compare different VC concentrations corresponding to $\mathrm{VC}$ to graphite surface area ratios typically used in commercial-scale cells. At low VC concentrations $(0.09 \mathrm{wt} \%$, corresponding to $1 \mathrm{wt} \%$ in commercial-scale cells), an impedance increase exclusively on the anode and an improved capacity retention is observed, whereas higher VC concentrations ( $0.17 \mathrm{wt}-2 \mathrm{wt} \%$, corresponding to $2 \mathrm{wt}-23 \mathrm{wt} \%$ in commercial-scale cells) show an increase in both cathode and anode impedance as well as worse cycling performance and overcharge capacity during the first cycle. By considering the onset potentials for $\mathrm{VC}$ reduction and oxidation in graphite/LNMO cells, we demonstrate that low amounts of VC can be reduced before VC oxidation occurs, which is sufficient to effectively passivate the graphite anode.

(C) The Author(s) 2017. Published by ECS. This is an open access article distributed under the terms of the Creative Commons Attribution Non-Commercial No Derivatives 4.0 License (CC BY-NC-ND, http://creativecommons.org/licenses/by-nc-nd/4.0/), which permits non-commercial reuse, distribution, and reproduction in any medium, provided the original work is not changed in any way and is properly cited. For permission for commercial reuse, please email: oa@electrochem.org. [DOI: 10.1149/2.1441712jes] All rights reserved.

(cc) BY-NC-ND
\end{abstract}

Manuscript submitted June 26, 2017; revised manuscript received August 16, 2017. Published August 31, 2017. This was Paper 567 presented at the Honolulu, Hawaii, Meeting of the Society, October 2-7, 2016.

During the first charge of a lithium ion battery (LiB), the so called solid electrolyte interphase $(\mathrm{SEI})^{1}$ is formed on the surface of the negative electrode. The standard electrolyte for $\mathrm{LiBs}$ consists of a mixture of cyclic and linear carbonates, e.g., ethylene carbonate (EC) and ethyl methyl carbonate (EMC), typically with lithium hexafluorophosphate $\left(\mathrm{LiPF}_{6}\right)$ as salt. Starting from a potential of $\sim 0.8 \mathrm{~V} \mathrm{vs.} \mathrm{Li} / \mathrm{Li}^{+}, \mathrm{EC}$ is reduced electrochemically into ethylene gas and lithium ethylene dicarbonate (LEDC), which is a key component of the SEI. ${ }^{2,3}$ Vinylene carbonate (VC) is one of the most effective additives to modify the SEI on graphite anodes, as it is reduced at potentials more positive than $1.0 \mathrm{~V}$ vs. $\mathrm{Li} / \mathrm{Li}^{+}$and hence suppresses the reduction of $\mathrm{EC} .^{4,5}$ Aurbach et al. have used VC as electrolyte additive in an EC/DMC (dimethyl carbonate) based electrolyte and that time reported a reduction of the irreversible capacity in the first cycles and an improved cycling stability at elevated temperatures for graphite anodes. The SEI resulting from the reduction of $\mathrm{VC}$ consists mainly of poly (vinylene carbonate) (poly(VC)). ${ }^{4,6}$

Important studies on the impact of different VC concentrations in graphite/NMC pouch cells have been carried out by the Dahn group. For example, Burns et al. ${ }^{7}$ investigated the effect of different concentrations of $\mathrm{VC}(0,1$ and $2 \mathrm{wt} \%)$ on cycle life and impedance growth of full-cells with graphite anodes and either $\mathrm{LCO}\left(\mathrm{LiCoO}_{2}\right)$ or NMC $\left(\mathrm{Li}\left(\mathrm{Ni}_{0.42} \mathrm{Mn}_{0.42} \mathrm{Co}_{0.16}\right) \mathrm{O}_{2}\right)$ cathodes, employing galvanostatic cycling experiments coupled with high precision coulombic efficiency and electrochemical impedance spectroscopy (EIS) measurements. For cells with VC additive, they observed higher coulombic efficiencies and reduced capacity fading, whereby a notable increase in cell impedance was observed for cells with $2 \mathrm{wt} \% \mathrm{VC}$, which they attributed to a thicker SEI-film at the surface of the anode. However, since it is known that LCO cathodes can also form a resistive surface film in the presence of $\mathrm{VC}$ additive (presumably consisting of poly $(\mathrm{VC})^{8,9}$ ), an assignment of the overall cell impedance growth to the individual contributions from anode and cathode requires more advanced techniques, like the symmetric cell approach. ${ }^{10}$ Thus, later on, Burns et al. ${ }^{10}$ investigated the effect of VC $(0-6 \mathrm{wt} \%)$ over extended charge/discharge cycling of graphite/NMC 18650 cells on anode and cathode impedance growth via symmetric cell measurements. They

\footnotetext{
*Electrochemical Society Member.

**Electrochemical Society Fellow.

${ }^{z}$ E-mail: daniel.pritzl@tum.de
}

showed that indeed the impedance of the negative electrode increases nearly linearly with VC concentration, whereas the impedance of the positive electrode first decreases as the $\mathrm{VC}$ concentration is increased to $2 \mathrm{wt} \%$ and then only increases gradually at higher VC concentrations. The strong anode impedance growth suggests that $\mathrm{VC}$ is mostly consumed at the graphite anode, leading to SEI growth. This is consistent with a study by Petibon et al., ${ }^{11}$ who analyzed the consumption of vinylene carbonate in graphite/NMC pouch cells and showed that the additive is mainly consumed at the anode side (both during high temperature formation $\left(50^{\circ} \mathrm{C}\right)$ and during a potential hold at $4.2 \mathrm{~V}$ cell voltage). In addition, they found that nearly $2 \mathrm{wt} \% \mathrm{VC}$ were consumed during formation, so that little residual VC remained after formation for VC concentrations of $\leq 2 \mathrm{wt} \%$. In a subsequent study, Petibon et al. ${ }^{12}$ also showed that residual VC after formation leads to a fast decay in the open-circuit voltage during storage in cells charged to $4.4 \mathrm{~V}$ cell voltage, caused by the poor oxidative stability of VC.

In a recent study from our group, ${ }^{13}$ we compared the effect of different $\mathrm{VC}$ concentrations on the impedance of graphite anodes in graphite/LFP $\left(\mathrm{LiFePO}_{4}\right)$ full-cells, using a Swagelok T-cell configuration with a reference electrode which enables the deconvolution of the overall cell impedance into the individual contributions from anode and cathode. There, we showed that the $\mathrm{VC}$ to active material ratio (expressed as the ratio of VC mass to graphite surface area in the cell), rather than the concentration of the additive in the electrolyte, is a key parameter when comparing results using different types of battery cell hardware. Basically, the cell hardware can roughly be categorized either into lab-scale-cells with a small total capacity $(<10 \mathrm{mAh}$, i.e., $<5 \mathrm{~cm}^{2}$ electrode area), which due to design constraints require a high electrolyte/active material mass ratio in order to function properly (e.g., coin or Swagelok T-cells), or into commercial-scale cells with a high total capacity ( $>100 \mathrm{mAh}$, i.e., $>20 \mathrm{~cm}^{2}$ electrode area), which are assembled with much lower electrolyte/active material mass ratios (e.g., multi-layer pouch or 18650 cells with low electrolyte/active material mass ratio). Consequently, the electrolyte/active material mass ratio in the latter is $\sim 12$-fold lower compared to commonly used lab-scale cells, so that a concentration of $2 \mathrm{wt} \% \mathrm{VC}$ in the study from Burns et al. ${ }^{10}$ based on 18650 cells would corresponds to $\sim 0.17 \mathrm{wt} \% \mathrm{VC}$ in a typical lab-scale cell. This scaling factor between commonly used lab-scale cells and commercial-scale cells needs to be considered when using lab-scale cells to evaluate the effect of additives. 
While the above discussed studies show that the cathode impedance growth with VC additive is generally small for graphite/ LCO and graphite/NMC cells operating at cell voltages up to $4.4 \mathrm{~V}$, this is not the case when higher voltage cathode active materials such as high-voltage spinel $\mathrm{LiNi}_{0.5} \mathrm{Mn}_{1.5} \mathrm{O}_{4}$ (LNMO) are used. $\mathrm{Li}$ et al. ${ }^{14}$ have shown that the cell performance of graphite/LNMO cells drastically decreases when 1 or $2 \mathrm{wt} \%$ of $\mathrm{VC}$ are added to the electrolyte, consistent with studies by Lee et al. ${ }^{15}$ and Song et al., ${ }^{16}$ which demonstrated that the oxidative stability of VC is insufficient for operation with an LNMO cathode. The oxidative instability of VC was examined in more detail in a recent study from the group of Brett Lucht: ${ }^{17}$ By means of ex-situ surface analysis (XPS and FT-IR) they showed that the oxidation of $\mathrm{VC}$ starts at already $\sim 4.5 \mathrm{~V} \mathrm{vs}$. $\mathrm{Li}^{\prime} / \mathrm{Li}^{+}$, leading to the formation of poly (VC) at the surface of the LNMO cathode. Even though these studies demonstrate that $\mathrm{VC}$ is not a suitable additive for cells with LNMO cathodes, they were all based on lab-scale cell setups with a high electrolyte/active material ratio, so that the ratio of VC mass over graphite surface area for the used VC concentrations of 1-2 wt\% was roughly an order of magnitude higher than what would be present in commercial-scale cells.

The additive VC behaves very differently in high-voltage cells compared to fluorinated additives. Fluoroethylene Carbonate (FEC) is often used in this type of cells, leading to an overall increased battery performance. On the one hand both additives (VC and FEC) generate $\mathrm{CO}_{2}$ during reduction, ${ }^{5,18}$ thus improving the anode SEI. On the other hand, FEC is more stable towards oxidation ${ }^{19}$ (compared to $\mathrm{VC}$ ) and can thus be used in large concentrations/quantities even at high voltages (e.g., with LNMO or HE-NCM cathodes).

In the present study, we therefore want to investigate much lower VC concentrations in the electrolyte in lab-scale cell tests $(0.09-0.52$ $\mathrm{wt} \% \mathrm{VC})$, which would correspond to VC concentrations of 1-6 wt\% in commercial-scale cells for the same ratio of $\mathrm{VC}$ mass to graphite surface area. The first part of our investigation aims to understand the drastic decrease in cell performance when large amounts of $\mathrm{VC}$ are added to graphite/LNMO cells (i.e., at very high ratios of VC mass to graphite surface area). To this end, we will examine the anodic stability of VC via on-line electrochemical mass spectrometry (OEMS) using carbon black model electrodes and a VC-only electrolyte with $1 \mathrm{M} \mathrm{LiPF}_{6}$. As a next step, we conduct impedance measurements in graphite/LNMO cells using a micro-reference electrode, ${ }^{13}$ quantifying anode and cathode impedance after formation in electrolytes with different amounts of $\operatorname{VC}(0.09,0.17,0.52$, and $2 \mathrm{wt} \%)$. In the second part, we examine the impact of different $\mathrm{VC}$ concentrations on the cycling behavior of graphite/LNMO cells and on anode/cathode impedance during cycling at $40^{\circ} \mathrm{C}$. We also show that the additional capacity during the first charge correlates with the impedance of the LNMO cathode. Finally, by comparing the impedance growth of the graphite anode in cells with either an LNMO or an LFP cathode, we can clearly show that VC is consumed at the LNMO cathode, resulting in a lower impedance of the of the graphite anode in a graphite/LNMO vs. a graphite/LFP cell.

\section{Experimental}

Electrode preparation.- $\mathrm{LiNi}_{0.5} \mathrm{Mn}_{1.5} \mathrm{O}_{4}$ (LNMO) electrodes were prepared by mixing LNMO (BASF SE, Germany), carbon black (Super C65, Timcal), and polyvinylene difluoride (PVDF, Kynar) at a mass ratio of 92/5/3 with NMP (N-methyl pyrrolidone, anhydrous, Sigma-Aldrich, Germany) in a planetary mixer (Thinky Corp.) for $15 \mathrm{~min}$. The ink was coated onto aluminum foil (MTI, $18 \mu \mathrm{m}$ ) with a doctor blade coater and dried afterwards at $50^{\circ} \mathrm{C}$ in a convection oven for at least $3 \mathrm{~h}$. The final LNMO coating had a loading of $\sim 13.6$ $\mathrm{mg}_{\mathrm{LNMO}} / \mathrm{cm}^{2}$, corresponding to $\sim 1.9 \mathrm{mAh} / \mathrm{cm}^{2}$. Electrodes with a diameter of $11 \mathrm{~mm}\left(\equiv 0.95 \mathrm{~cm}^{2}\right)$ were punched out and compressed to $\sim 30 \%$ porosity with a $\mathrm{KBr}$ press. Graphite electrodes were prepared by mixing graphite (T311, SGL Carbon, Germany) and PVDF at a mass ratio of $95 / 5$ with NMP by applying the same procedure as for the positive electrodes. The graphite ink was coated onto copper foil (MTI, $\sim 12 \mu \mathrm{m}$ ) and dried in a convection oven at $50^{\circ} \mathrm{C}$ for $3 \mathrm{~h}$. The loading of the graphite coating was $\sim 7 \mathrm{mg}_{\text {graphite }} / \mathrm{cm}^{2}$ corresponding to $\sim 2.6 \mathrm{mAh} / \mathrm{cm}^{2}$. The electrodes were punched out with a diameter of $11 \mathrm{~mm}$ and compressed to a porosity of $\sim 30 \%$. Both types of electrodes were dried under dynamic vacuum at $120^{\circ} \mathrm{C}$ for at least $12 \mathrm{~h}$ in a vacuum oven (Büchi, Switzerland) and then transferred into an Argon-filled glove box (MBraun, Germany) without exposure to air.

For OEMS measurements, isotopically labelled ${ }^{13} \mathrm{C}$-electrodes were prepared by dispersing ${ }^{13} \mathrm{C}$-carbon (BET $\sim 140 \mathrm{~m}^{2} / \mathrm{g}, 99 \%$ isotopic purity, Sigma-Aldrich, Germany) in NMP with an ultrasonication horn. PVDF was dissolved in NMP to yield a $10 \% \mathrm{wt}$ solution. The PVDF solution was added to the ${ }^{13} \mathrm{C}$-dispersion to yield a final mass ratio of 1:2 (PVDF: $:{ }^{13} \mathrm{C}$ ), and stirred carefully. The ink was then coated onto a polyester separator (Freudenberg, Germany) with a wedge bar and dried in a convection oven at $50^{\circ} \mathrm{C}$. Afterwards, electrodes with a diameter of $15 \mathrm{~mm}$ were punched out, dried under dynamic vacuum at $120^{\circ} \mathrm{C}$ over night and transferred into an argon-filled glove box. The final electrodes had a loading of $\sim 1 \mathrm{mg}_{\mathrm{C}} / \mathrm{cm}^{2}$.

On-line electrochemical mass spectrometry.-The on-line electrochemical mass spectrometry (OEMS) setup has been described in more detail in a previous publication by our group. ${ }^{20}$ For the experiments in this study, we used a recently developed sealed 2compartment cell, ${ }^{21}$ where working and counter electrode are separated by a sealed lithium-ion conductive glass ceramics (Ohara Corp., Japan). In this way, only gases coming directly from the working electrode are detected, and any gas evolution related to the lithium counter electrode or electrode crosstalk can be avoided. The cells were assembled with a lithium counter electrode $(\varnothing 17 \mathrm{~mm}, 450 \mu \mathrm{m}$ thickness, Rockwood Lithium, USA), a glassfiber separator soaked with 250 $\mu \mathrm{L}$ electrolyte in the lower compartment and a polyester separator soaked with $100 \mu \mathrm{L}$ electrolyte in the upper compartment. The investigated electrolytes consisted only of EC or $\mathrm{VC}_{\text {with }} 1 \mathrm{M} \mathrm{LiPF}_{6}$ (all from BASF SE, Germany). To distinguish between electrolyte oxidation and carbon corrosion, we used isotopically labelled ${ }^{13} \mathrm{C}$-carbon electrodes coated on a polyester separator as working electrodes (see above). The oxidative stability of the electrolytes was investigated by a linear potential sweep from OCV $\left(\sim 3 \mathrm{~V}\right.$ vs. $\left.\mathrm{Li} / \mathrm{Li}^{+}\right)$to $5.5 \mathrm{~V}$ vs. $\mathrm{Li} / \mathrm{Li}^{+}$at a scan rate of $0.1 \mathrm{mV} / \mathrm{s}$. The quantification of the OEMS signals in terms of moles of produced gas was described previously, ${ }^{22}$ and gas evolution rates are reported in terms of $\mu \mathrm{mol}$ gas $/ \mathrm{m}^{2}$ BET of the ${ }^{13} \mathrm{C}$-electrode.

Electrochemical characterization.-Swagelok T-cells with a Gold Wire Reference Electrode $(\mathrm{GWRE})^{13}$ were assembled in an argon filled glove box $\left(\mathrm{O}_{2}\right.$ and $\mathrm{H}_{2} \mathrm{O}<0.1 \mathrm{ppm}$, MBraun, Germany) using two glass fiber separators (11 mm diameter, $200 \mu \mathrm{m}$ thickness, glass microfiber \#691, VWR, Germany) and $60 \mu \mathrm{L}$ of electrolyte. The electrolyte consisted of standard LP57 (1 M LiPF 6 in EC: EMC (3:7 $\mathrm{wt} / \mathrm{wt})<10 \mathrm{ppm} \mathrm{H}_{2} \mathrm{O}$, BASF, Germany) without and with different amounts of vinylene carbonate (VC, BASF SE, Germany), which was added at concentrations of $0.09,0.170 .52$ and $2 \mathrm{wt} \%$ to the electrolyte. The cells were assembled using a graphite anode, a LNMO cathode, and a gold wire reference electrode (GWRE). The detailed experimental procedure for the assembly can be found in Reference 13. For charge/discharge cycling, identical Swagelok T-cells without a reference electrode were assembled. Cell cycling was carried out in a climate chamber $\left(25^{\circ} \mathrm{C}\right.$ or $40^{\circ} \mathrm{C}$, Binder, Germany) with a battery cycler (Series 400, Maccor, USA). The cycling protocol consisted of the following steps: i) two formation cycles with $\mathrm{C} / 10$ at $25^{\circ} \mathrm{C}$, ii) charge/discharge cycling with $1 \mathrm{C}(20$ cycles $)$ at $40^{\circ} \mathrm{C}$, and iii) charge/discharge cycling with $1 \mathrm{C} / 3 \mathrm{C}(2$ cycles $)$ at $40^{\circ} \mathrm{C}$. The steps ii) and iii) were repeated five times. All cycles were performed between $3.5 \mathrm{~V}-4.8 \mathrm{~V}$ cell voltage, using a constant current constant voltage (CCCV) charge with a current limit of $\mathrm{C} / 20$ for the constant voltage phase and a constant current (CC) discharge. The C-rate is referenced to the theoretical capacity of the LNMO cathode $\left(140 \mathrm{mAh} / \mathrm{g}_{\mathrm{LNMO}}\right)$, i.e., $1 \mathrm{C}$ corresponds to $140 \mathrm{~mA} / \mathrm{g}_{\mathrm{LNMO}}$. or $\sim 1.9 \mathrm{~mA} / \mathrm{cm}^{2}$.

Electrochemical impedance spectroscopy (EIS) measurements on graphite/LNMO cells with GWRE were conducted after the first 
formation cycle at 50\% SOC (charged to $50 \%$ SOC with $\mathrm{C} / 10$ ) and after the $22^{\text {nd }}, 66^{\text {th }}$ and $102^{\text {nd }}$ (charged to $50 \%$ SOC with $1 C$ ) using a potentiostat (VMP300, BioLogic, France). Prior to the impedance measurement, the cells were charged to $50 \%$ SOC, transferred to a climate chamber set to $10^{\circ} \mathrm{C}$, and stored for $1 \mathrm{~h}$ in order to ensure a constant temperature of the cells. Galvanostatic electrochemical impedance spectroscopy (GEIS) was used in a frequency range from $100 \mathrm{kHz}-100 \mathrm{mHz}$ with an amplitude of $0.6 \mathrm{~mA}$.

In a previous study ${ }^{13}$ we have demonstrated the stability of the GWRE reference potential $\left(0.31 \mathrm{~V}\right.$ vs. $\left.\mathrm{Li} / \mathrm{Li}^{+}\right)$in graphite/LFP cells to be $>500 \mathrm{~h}$. By replacing the LFP electrode (upper cut off potential $\sim 4.1 \mathrm{~V}$ vs. $\mathrm{Li} / \mathrm{Li}^{+}$) by a $\mathrm{LiNi}_{0.5} \mathrm{Mn}_{1.5} \mathrm{O}_{4}$ electrode (upper cut off potential $\sim 4.9 \mathrm{~V}$ vs. $\mathrm{Li} / \mathrm{Li}^{+}$), the long-term stability of the GWRE reference potential is limited. The potential drift observed in the latter case might be caused by oxidation products generated at the highvoltage positive electrode (LNMO) and their subsequent reduction at the exposed surface of the gold wire, leading to an oxidation of the lithium-gold alloy (i.e., to its gradual delithiation). To overcome this issue, relithiation of the GWRE (at $150 \mathrm{nA}$ for $1 \mathrm{~h}$, consuming $<0.1 \%$ of the capacity of the LNMO electrode during each charge) is carried out before each impedance measurement. A similar observation is reported by Klett et al., ${ }^{23}$ who also relithiated their $\mathrm{Li}_{\mathrm{x}} \mathrm{Sn}$ reference electrode prior to each impedance measurement.

\section{Results}

Anodic stability of vinylene carbonate (VC) investigated via online electrochemical mass spectrometry (OEMS).-Until now, the detrimental oxidation of $\mathrm{VC}$ is regarded as a major obstacle for the successful use of VC in LNMO cells. ${ }^{14-17}$ In order to investigate the onset potential for $\mathrm{VC}$ oxidation and its products, we performed on-line electrochemical mass spectrometry on electrolytes based on only $\mathrm{VC}$ or EC mixed with $1 \mathrm{M} \mathrm{LiPF}_{6}$. For these experiments, we used carbon black electrodes made from isotopically labelled ${ }^{13} \mathrm{C}$ carbon, so that we can track the gas evolution from the unlabeled ${ }^{12} \mathrm{C}$-electrolyte by monitoring the corresponding ${ }^{12} \mathrm{C}$-related signals of $\mathrm{CO}_{2}$ and $\mathrm{CO}^{22}$ As Jung et al. ${ }^{24}$ recently showed that the onset and extent of electrolyte oxidation on LNMO and carbon black is identical, it is safe to transfer the results obtained from the ${ }^{13} \mathrm{C}$-carbon model electrodes to real LNMO cathodes later on. To avoid crosstalk between oxidized species and the lithium counter electrode, we used our sealed 2-compartment cell setup. ${ }^{21}$ In this way, only the direct oxidation of the pure electrolyte is observed. Figure 1 shows the current profile (a) and the gas evolution (b) of ${ }^{12} \mathrm{CO}_{2}(\mathrm{~m} / \mathrm{z}=44$, solid lines $)$ and ${ }^{12} \mathrm{CO}(\mathrm{m} / \mathrm{z}$ $=28$, dotted lines) during an oxidative scan in either EC-only or VConly electrolytes with $1 \mathrm{M} \mathrm{LiPF}_{6}$ from $\mathrm{OCV}\left(\sim 3 \mathrm{~V} \mathrm{vs} . \mathrm{Li}^{\prime} / \mathrm{Li}^{+}\right)$to $5.3 \mathrm{~V}$ vs. $\mathrm{Li} / \mathrm{Li}^{+}$. While the current signal includes processes like capacitive currents related to the electrode surface or $\mathrm{PF}_{6}{ }^{-}$intercalation into the graphitic domains of the conductive carbon, which is reported to start around $4.6 \mathrm{~V}$ vs. $\mathrm{Li} / \mathrm{Li}^{+},{ }^{25,26}$ we believe that the evolution of gaseous electrolyte oxidation products is a more meaningful indicator for the onset of electrolyte oxidation. As expected, Figure $1 \mathrm{~b}$ shows that the oxidative $\mathrm{CO}_{2}$-release of $\mathrm{VC}$ starts at significantly lower potentials $\left(\sim 4.3 \mathrm{~V}\right.$ vs. $\left.\mathrm{Li} / \mathrm{Li}^{+}\right)$compared to $\mathrm{EC}\left(\sim 4.8 \mathrm{~V}\right.$ vs. $\left.\mathrm{Li} / \mathrm{Li}^{+}\right)$. The small current starting at $\sim 3.7 \mathrm{~V}$ vs. $\mathrm{Li} / \mathrm{Li}^{+}$for $\mathrm{VC}$ is most likely related to the oxidation of the BHT stabilizer (butylated hydroxytoluene), as its integration between $3.67 \mathrm{~V}$ and $4.0 \mathrm{~V}$ yields a charge of $10.2 \mathrm{mAs}$ compared to the $11.9 \mathrm{mAs}$ theoretically needed for the 1-electron oxidation of the $200 \mathrm{ppm}$ BHT contained in VC. Interestingly, there is no $\mathrm{CO}$ evolution resulting from the oxidation of $\mathrm{VC}$ (See red dotted line in Figure 1b); on the other hand, the electrooxidation of EC yields both $\mathrm{CO}_{2}$ and small amounts of $\mathrm{CO}$ (see black dotted lines in Figure 1 , bottom panel), as we had discussed previously. ${ }^{27}$

The lower anodic stability of VC compared to EC has already been demonstrated by previous experimental results ${ }^{15,17,28}$ and calculations. ${ }^{29,30}$ The $\mathrm{CO}_{2}$ evolution from $\mathrm{VC}$ at potentials above $\sim 4.3 \mathrm{~V}$ vs. $\mathrm{Li} / \mathrm{Li}^{+}$(see Figure $1 \mathrm{~b}$ ), corresponding to $\sim 4.2 \mathrm{~V}$ cell voltage in a full-cell with a graphite anode, fits well to the observation made by the Dahn group ${ }^{11,31-33}$ that commercials cells containing VC

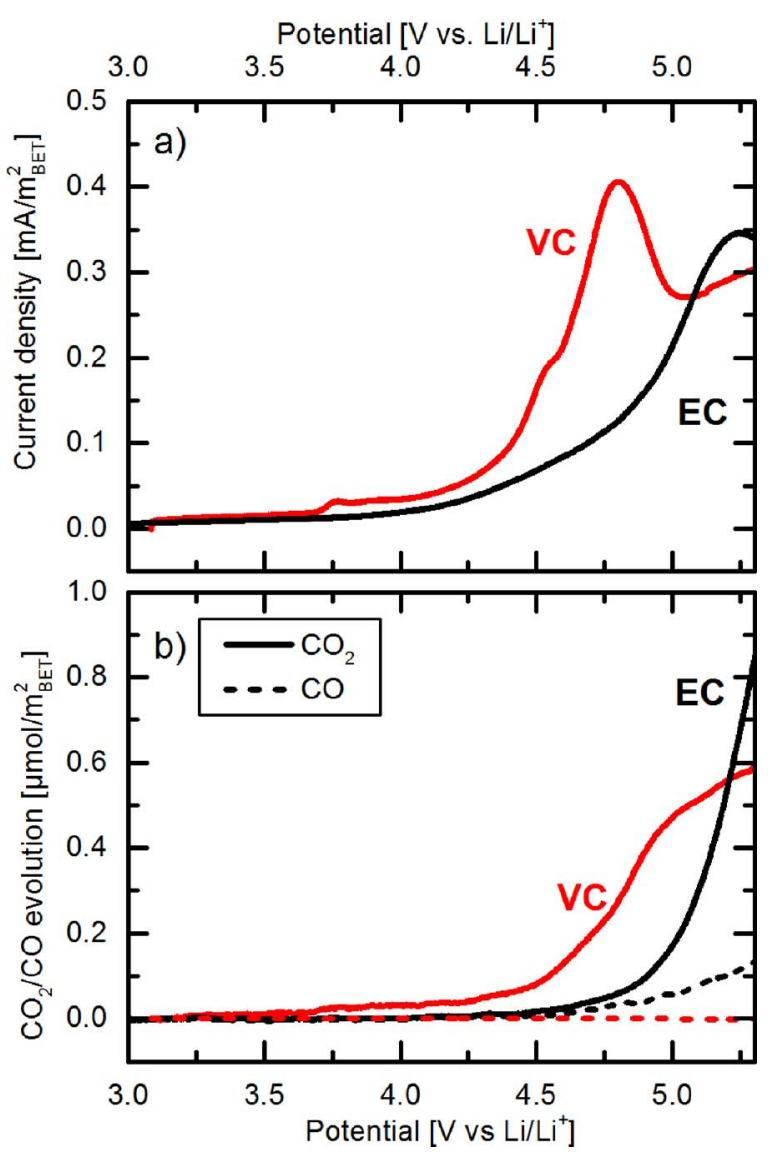

Figure 1. Anodic current (a) and evolution of ${ }^{12} \mathrm{CO}_{2}$ (b, solid lines) and ${ }^{12} \mathrm{CO}$ (b, dotted lines) from the electrolyte during a linear scan from OCV to $5.3 \mathrm{~V}$ vs. $\mathrm{Li} / \mathrm{Li}^{+}(0.1 \mathrm{mV} / \mathrm{s})$ on a ${ }^{13} \mathrm{C}$ carbon electrode in electrolytes containing only $\mathrm{EC}$ (black lines) or $\mathrm{VC}$ (red lines) and $1 \mathrm{M} \mathrm{LiPF}_{6}$. The experiments were performed using on-line electrochemical mass spectrometry and a sealed 2-compartment cell $^{21}$ to avoid crosstalk with the lithium counter electrode.

evolve more gas when held at high potentials compared to the same cells without VC electrolyte. According to the EC oxidation mechanism proposed by Xing et al. ${ }^{34}$ and Li et al., ${ }^{35} \mathrm{CO}_{2}$ is readily abstracted after ring opening of the $\mathrm{EC}$ radical cation (Scheme 1, black pathway 1a), while the evolution of CO from EC is energetically less favorable and only occurs with a simultaneous breaking of the $\mathrm{CH}_{2}-\mathrm{CH}_{2}$ bond after the intial ring opening (see blue pathway $1 \mathrm{~b}$ in Scheme 1); for further discussion see Ref. 21). Although the decomposition mechanism of EC resulting in $\mathrm{CO}_{2}$ can easily be applied to $\mathrm{VC}$ (see black pathway 2a in Scheme 1), the analogous pathway leading to $\mathrm{CO}$ is likely to present a very large barrier in the case of $\mathrm{VC}$, as this would require breaking the much stronger $\mathrm{CH}=\mathrm{CH}$ bond. Hence, our observation that no $\mathrm{CO}$ is produced during $\mathrm{VC}$ oxidation (Figure $1 \mathrm{~b}$ ) would be consistent with an analogous ring opening reaction as in the case of EC, which disagrees however with the early modeling predictions made by Zhang et al. ${ }^{5}$ As poly(VC) has been found on electrodes cycled to high potentials in VC-containing electrolytes, ${ }^{17}$ we assume that the radical cations formed in (2a) can trigger a radical polymerization reaction of $\mathrm{VC}$ to poly $(\mathrm{VC})$ (see green pathway $2 \mathrm{~b}$ in Scheme 1). ${ }^{9,17}$

Extracting the interfacial resistance from the impedance spectra.-As a next step, cells with different VC concentrations are assembled and impedance spectra are collected in order to understand the impact of the anodic decomposition of the additive in a graphite/LNMO full-cell. To extract the interfacial resistance from the anode Nyquist plots, the equivalent circuit shown in Figure 2a is used: i) the high frequency resistance (HFR) $R_{H F R}$ represents the 


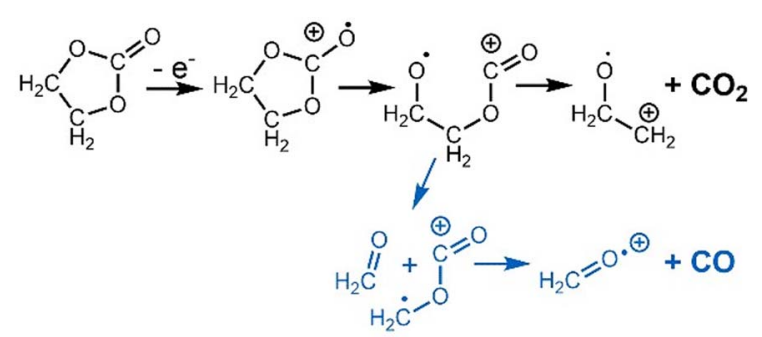

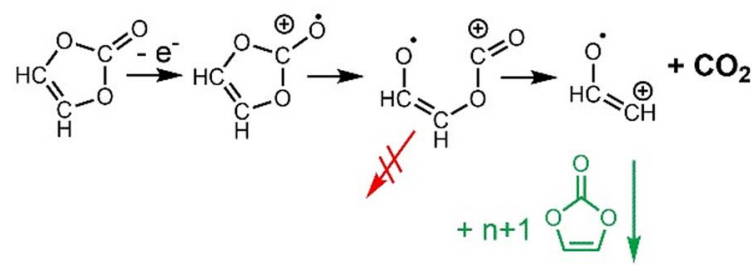

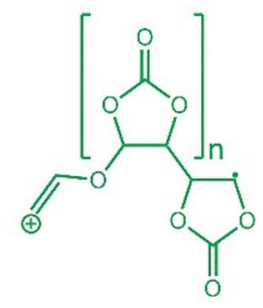

Scheme 1. Oxidation mechanism of EC leading to $\mathrm{CO}_{2}$ (1a, black) and $\mathrm{CO}$ (1b, blue) as proposed by Xing et al., ${ }^{34}$ oxidation mechanism of $\mathrm{VC}$ leading to $\mathrm{CO}_{2}$ (2a, black) and poly(VC) (2b, green).

contributions from the ionic conduction in the separator (between the GWRE and the respective electrode) and external electrical contact resistances; ii) up to three RQ-elements (resistor and constant-phase element in parallel) are used to determine the overall resistance of the anode, consisting of contributions from the charge transfer resistance, the solid-electrolyte interphase resistance, and one as yet unknown impedance contribution at low frequencies when high VC concentrations $(0.52$ and $2 \mathrm{wt} \%)$ are used (see Figure $3 \mathrm{a})$; iii) the Warburg element $\left(Z_{W}\right)$ mostly represents the diffusion of lithium in the liquid electrolyte phase as described in Reference 36. For the LNMO cathode, the equivalent circuit shown in Figure $2 b$ is used, representing the analogous processes as in the case of the anode. Since the main focus of this study was to determine the individual impedance growth of anode and cathode during formation and extended charge/discharge cycling, only the overall anode and cathode impedance will be considered in the following $\left(\mathrm{R}_{\text {Anode }}=\mathrm{R}_{1}+\mathrm{R}_{2}+\mathrm{R}_{3}\right.$, see Figure $2 \mathrm{a}$; $\mathrm{R}_{\text {Cathode }}=\mathrm{R}_{1}+$ $R_{2}$ see Figure $\left.2 b\right)$. After the $22^{\text {th }}$ cycle, a semi-circle at high frequencies appears in the cathode impedance spectra, which was shown to be due to the formation of a contact resistance at the interface between the cathode electrode and the cathode current collector, ${ }^{36}$ and which will be omitted from the fitting process in this study. Unfortunately, a meaningful deconvolution/assignment of the individual impedance contributions to the overall impedance for each electrode would require more elaborate experiments, as we have shown in our recent work for the LNMO cathode impedance. ${ }^{36}$ However, as explained above, the main objective of this study was to quantify the individual evolution of anode $\left(R_{\text {Anode }}\right)$ vs. cathode $\left(R_{\text {Cathode }}\right)$ impedance over extended charge/discharge cycling, for which a deconvolution into the various process is not necessary.

Figures $2 \mathrm{c}$ and $2 \mathrm{~d}$ show exemplary Nyquist plots of a graphite anode and a LNMO cathode after one formation cycle in a graphite/LNMO full-cell with $0.09 \mathrm{wt} \% \mathrm{VC}$ additive. The red points represent the experimental spectra $(100 \mathrm{kHz}-100 \mathrm{mHz}$, current perturbation of $0.6 \mathrm{~mA}, 10^{\circ} \mathrm{C}$ ), while the black line represents the fit to the equivalent circuit shown in Figures $2 \mathrm{a}$ and $2 \mathrm{~b}$. The values for the HFR of anode and cathode are $\sim 4.0$ and $\sim 3.5 \Omega \mathrm{cm}^{2}$, respectively;
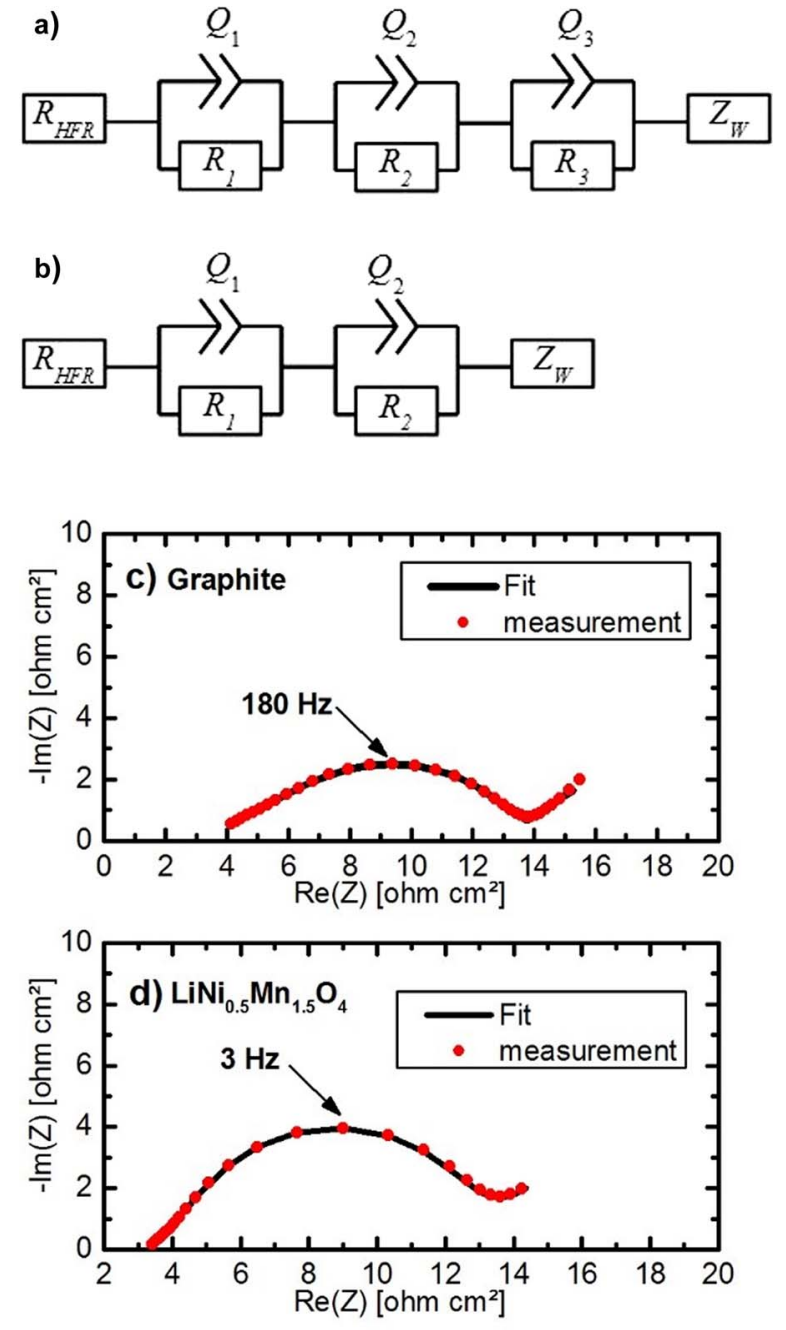

Figure 2. Equivalent circuit models for fitting the anode (a) and the cathode (b) impedance spectra. The Nyquist plots after one formation cycle and recharge to $50 \% \mathrm{SOC}$ (at $0.1 \mathrm{C}$ and $40^{\circ} \mathrm{C}$ ) of graphite/LNMO cells with LP57 electrolyte with $0.09 \mathrm{wt} \% \mathrm{VC}$ are shown for both the graphite anode (c) and the LNMO cathode (d), whereby the experimental data (red points) are compared to the corresponding fit of the measurement (black line). The impedance is measured from $100 \mathrm{kHz}$ to $100 \mathrm{mHz}$ with an amplitude of $0.6 \mathrm{~mA} @ 10^{\circ} \mathrm{C}$ and $50 \%$ SOC.

the cause for the slight difference in these HFR values (which are expected to be identical for a symmetric placement of the GWRE) was described elsewhere. ${ }^{13}$ The overall resistances of the anode $\left(R_{\text {Anode }}\right)$ and the cathode $\left(R_{\text {Cathode }}\right)$ are in both cases $\sim 10 \Omega \mathrm{cm}^{2}$.

Impedance analysis after the first formation cycle.-The OEMS measurement showed an onset for the anodic decomposition of $\mathrm{VC}$ at $\sim 4.3 \mathrm{~V} \mathrm{vs} . \mathrm{Li} / \mathrm{Li}^{+}$, accompanied by the release of $\mathrm{CO}_{2}$. To understand the effect of the VC decomposition products formed by VC oxidation on the cathode (e.g., poly(VC) and radicals, see Scheme $2 \mathrm{a}$ and $2 \mathrm{~b}$ ) and by $\mathrm{VC}$ reduction on the anode (discussed in Reference 5) on cathode and anode impedance growth, we conduct impedance measurements with the gold-wire reference electrode (GWRE) after one formation cycle at $25^{\circ} \mathrm{C}$ and recharge to $50 \%$ SOC (state-of-charge) in LP57 with different concentrations of VC $(0,0.09,0.17,0.52$, and $2 \mathrm{wt} \%)$. The additive concentrations were chosen such that some of the VC concentrations in our lab-scale cells yield VC mass to graphite surface area ratios comparable to those tested in the commercial-scale pouch cell experiments by Burns et al.: ${ }^{10} 0.09,0.17$, and $2 \mathrm{wt} \% \mathrm{VC}$ in our labscale cells approximately corresponds to 1, 2, and $6 \mathrm{wt} \% \mathrm{VC}$ in their 

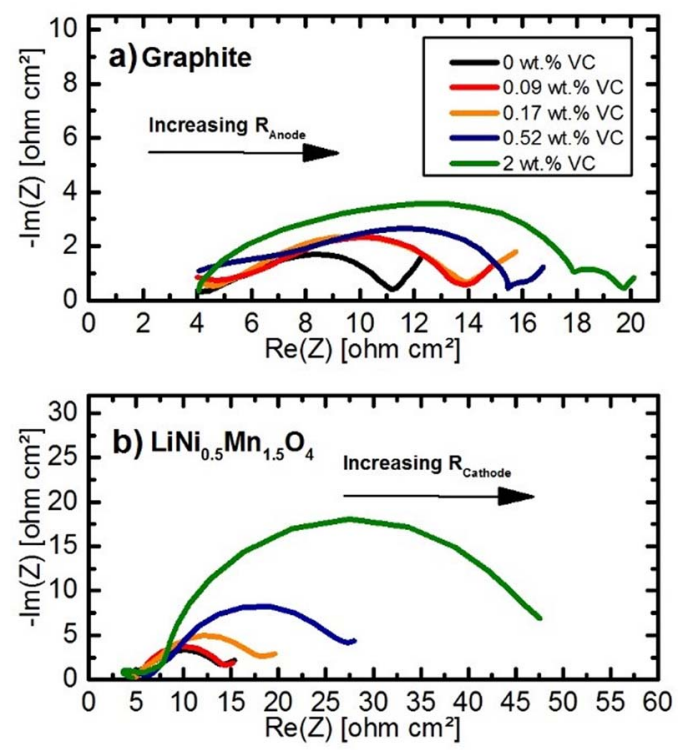

Figure 3. Anode and cathode impedances obtained from graphite/LNMO fullcell with GWRE after one formation cycle and recharge to $50 \% \mathrm{SOC}$ at $25^{\circ} \mathrm{C}$ in LP57 with various VC additive concentrations. a) Impedance spectra of the graphite anode of cells containing $0 \mathrm{wt} \% \mathrm{VC}$ (black lines), $0.09 \mathrm{wt} \% \mathrm{VC}$ (red lines), $0.17 \mathrm{wt} \% \mathrm{VC}$ (orange lines), $0.52 \mathrm{wt} \% \mathrm{VC}$ (blue lines), and 2 wt $\%$ VC (green lines); b) analogous impedance spectra of the LNMO cathode. Impedance spectra were measured from $100 \mathrm{kHz}$ to $100 \mathrm{mHz}$ with a current amplitude of $0.6 \mathrm{~mA}$ at a temperature of $10^{\circ} \mathrm{C}$ and at $50 \%$ SOC.

commercial-scale cells. In addition, to allow for a better comparison of the resulting anode and cathode impedance, we also conducted our impedance measurements at $10^{\circ} \mathrm{C}$, as done in the latter study. Figures $3 \mathrm{a}$ and $3 \mathrm{~b}$ show the Nyquist plots of the graphite and the LNMO electrodes recorded from a graphite/LNMO full-cell with GWRE.

Without VC additive (black lines), the fitted values for the overall resistance of the anode, $R_{\text {Anode }}$, are $\sim 7 \Omega \mathrm{cm}^{2}$ and $\sim 9 \Omega \mathrm{cm}^{2}$ for $\mathrm{R}_{\text {Cathode }}$. When a small amount of VC ( $0.09 \mathrm{wt} \%$, red lines) is added to the cells, the overall resistance of the anode increases to $\sim 10 \Omega \mathrm{cm}^{2}$, whereas the impedance of the cathode stays constant at $\sim 9 \Omega \mathrm{cm}^{2}$. When the concentration is increased to $0.17 \mathrm{wt} \%$ (orange lines), the impedance of the anode remains at $\sim 10 \Omega \mathrm{cm}^{2}$ while now the impedance of the cathode starts to increase to $\sim 13 \Omega \mathrm{cm}^{2}$. While the anode impedance only increases very little with a further rise in $\mathrm{VC}$ concentration, namely to $\sim 15 \Omega \mathrm{cm}^{2}$ for $0.52 \mathrm{wt} \% \mathrm{VC}$ (blue lines) and to $\sim 16$ $\Omega \mathrm{cm}^{2}$ for $2 \mathrm{wt} \%$ VC (green lines), the cathode impedance increases substantially to $\sim 22 \Omega \mathrm{cm}^{2}$ for $0.52 \mathrm{wt} \%$ VC and to $\sim 41 \Omega \mathrm{cm}^{2}$ for $2 \mathrm{wt} \% \mathrm{VC}$.

Our interpretation of these observations is as follows: When small amounts of VC $(0.09 \mathrm{wt} \%)$ are added to the graphite/LNMO cells, it will preferentially be reduced at the graphite anode, leaving no or little VC for oxidation at the LNMO cathode. On the other hand, when higher concentrations of $\mathrm{VC}$ are present in the electrolyte $(0.17-2 \mathrm{wt} \%)$, residual VC remains in the electrolyte after anode SEI formation, allowing for oxidation of VC at the high-voltage LNMO cathode, ultimately leading to cathode impedance growth. As already suggested in previous studies ${ }^{17}$ and shown in Scheme 1 (reactions $2 \mathrm{a}$ and $2 \mathrm{~b}$ ), the formation of a poly(VC) film on the LNMO cathode is the most likely explanation for the observed impedance increase of the positive electrode shown in Figure $3 \mathrm{~b}$. The very high cathode impedance of our lab-scale cell with $2 \mathrm{wt} \% \mathrm{VC}$ after only one formation cycle indicates that the rapid oxidation of $\mathrm{VC}$ at the LNMO cathode potential (shown by OEMS data in Figure 1) leads to the formation of a highly resistive surface film. This would be consistent with the strong capacity fading reported for graphite/LNMO coin cells with $2 \mathrm{wt} \% \mathrm{VC}^{14}$ and will be further examined in the following. These results suggest that the ratio of (anode) additive to graphite surface is

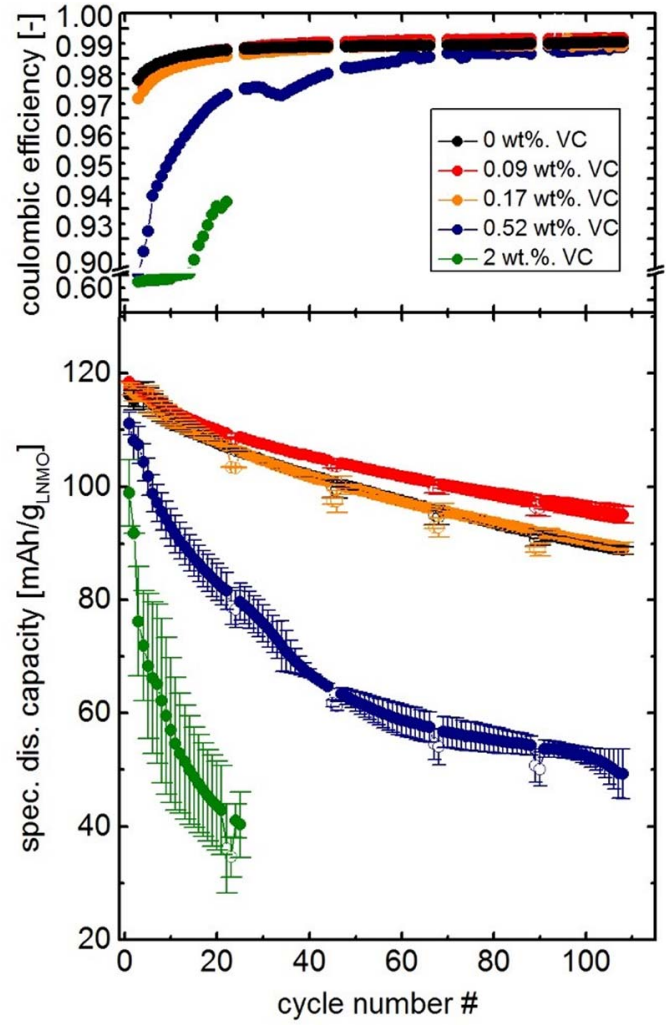

Figure 4. Coulombic efficiency (upper panel) and specific discharge capacity (mAh/g $\mathrm{g}_{\mathrm{LNMO}}$ ) (lower panel) of graphite/LNMO cells (without GWRE) over extended charge/discharge cycling at $1 \mathrm{C} / 1 \mathrm{C}$ (followed by two $1 \mathrm{C} / 3 \mathrm{C}$ cycles after every 20 cycles) and $40^{\circ} \mathrm{C}$ between 3.5 and $4.8 \mathrm{~V}$ in LP57 electrolyte with different VC concentrations: $0 \mathrm{wt} \% \mathrm{VC}$ (black points), $0.09 \mathrm{wt} \% \mathrm{VC}$ (red points), $0.17 \mathrm{wt} \% \mathrm{VC}$ (orange points), $0.52 \mathrm{wt} \% \mathrm{VC}$ (blue points), and $2.0 \mathrm{wt} \%$ $\mathrm{VC}$ (green points). The formation of the cells was carried out at $25^{\circ} \mathrm{C}(2$ cycles at $\mathrm{C} / 10$ ), while further cycling is done at $40^{\circ} \mathrm{C}$. For clarity, the upper panel does not contain data of the two formation cycles and the $1 \mathrm{C} / 3 \mathrm{C}$ cycles. The coulombic efficiencies of the two formation cycles (cycle 1 and 2) are given in Table I. Two cells were tested for each electrolyte composition; the figure shows the average of the two cells, with error bars representing the standard deviation. 3C discharge points are filled white for better visibility.

crucial for high-voltage lithium-ion cells, and that a successful use of SEI formers like VC will depend on the competition between additive reduction on the anode and its oxidation on the cathode, as will be explained in more detail in the Discussion section.

Cell cycling at elevated temperatures $\left(40^{\circ} \mathrm{C}\right)$ with different concentrations of vinylene carbonate $(V C)$.- As a next step, the influence of different $\mathrm{VC}$ concentrations on the cycling behavior at elevated temperatures $\left(40^{\circ} \mathrm{C}\right)$ will be investigated. The two main questions are: i) can low concentrations of VC have a beneficial effect on the cycling performance of graphite/LNMO cells, despite the current understanding that $\mathrm{VC}$ has a detrimental effect; and, ii) how do the $\mathrm{VC}$ oxidation products affect the capacity retention of full-cells. To address these questions, graphite/LNMO cells with different VC concentrations are cycled at $40^{\circ} \mathrm{C}$ at $1 \mathrm{C}$ (CCCV charge, CC discharge; for details see Experimental section) after formation at $25^{\circ} \mathrm{C}$ (two $\mathrm{C} / 10$ cycles). After every twentieth $1 \mathrm{C} / 1 \mathrm{C}$ charge/discharge cycle, two $1 \mathrm{C} / 3 \mathrm{C}$ charge/discharge cycles are employed in order to gain information about the resistance buildup in the cells, which later on will be compared with the anode/cathode impedance data acquired in repeat experiments using T-cells equipped with a gold wire reference electrode. Figure 4 shows both the specific discharge capacity (in $\mathrm{mAh} / \mathrm{g}_{\mathrm{LNMO}}$ ) versus the cycle number (bottom panel) and the coulombic efficiency (top panel) of graphite/LNMO cells with different VC concentrations. For clarity, each dataset shown in Figure 4 contains 
the average value of two identical cells (error bars represent the standard deviations between the two cells). Starting from cells which contain no VC ( $0 \%$ VC, black dots), the first discharge capacity at $\mathrm{C} / 10$ is $\sim 117( \pm 2) \mathrm{mAh} / \mathrm{g}_{\mathrm{LNMO}}$, resulting in a first-cycle coulombic efficiency of $\sim 82 \%$. After 80 cycles, the coulombic efficiency reaches a constant value of $\sim 99.5 \%$ while the discharge capacity remains at $\sim 88( \pm 1) \mathrm{mAh} / \mathrm{g}_{\mathrm{LNMO}}$ after 108 cycles. When adding VC at a commonly used concentration of $2 \mathrm{wt} \% \mathrm{VC}$ (Figure 4, green dots), the first-cycle discharge capacity at $\mathrm{C} / 10$ is only $\sim 99( \pm 6) \mathrm{mAh} / \mathrm{g}_{\mathrm{LNMO}}$, with a coulombic efficiency of $\sim 54 \%$, i.e, dramatically lower than in cells with VC-free electrolyte. The capacity loss for cells with $2 \mathrm{wt} \%$ $\mathrm{VC}$ is very high ( $57 \pm 3 \mathrm{mAh} / \mathrm{g}_{\mathrm{LNMO}}$ after 20 cycles), and the difference in capacity between the last $1 \mathrm{C} / 1 \mathrm{C}$ (cycle 25) and the previous $3 \mathrm{C} / 1 \mathrm{C}$ cycles amounts to $\sim 8( \pm 5) \mathrm{mAh} / \mathrm{g}_{\mathrm{LNMO}}$ (in contrast to $\sim 1$ $( \pm 1) \mathrm{mAh} / \mathrm{g}_{\mathrm{LNMO}}$ for $\mathrm{VC}$-free electrolyte at the same point), which indicates a dramatic increase in cell impedance. Owing to the already very low capacity after these initial 23 cycles, the test was discontinued here. The poor coulombic efficiency with $2 \mathrm{wt} \% \mathrm{VC}$ can partly be explained by the early onset of VC oxidation at a cell voltage of $\sim 4.2$ $\mathrm{V}$ (i.e., at $\sim 4.3 \mathrm{~V}$ vs. $\mathrm{Li} / \mathrm{Li}^{+}$), as evidenced by the OEMS data in Figure 1 , since a parasitic oxidation reaction would reduce the coulombic efficiency.

When the concentration of VC is lowered to $0.52 \mathrm{wt} \%$ (Figure 4, blue points), the first discharge capacity is $\sim 111( \pm 2) \mathrm{mAh} / \mathrm{g}_{\mathrm{LNMO}}$ and a first-cycle coulombic efficiency of $\sim 74 \%$ is obtained, which is much higher compared to cells with $2 \mathrm{wt} \% \mathrm{VC}$ (see Table I). After 108 cycles, the discharge capacity is $\sim 49( \pm 4) \mathrm{mAh} / \mathrm{g}_{\mathrm{LNMO}}$ and the coulombic efficiency increases up to $97.5 \%$ until cycle 30 , where it shows an unexplained drop until cycle 40 , and then gradually approaches $99 \%$ by the end of the test procedure. Also here, the low coulombic efficiency and capacity retention illustrate the negative impact of VC oxidation products on cell performance. When 0.17 wt $\%$ VC are added to the full-cell, a first-cycle discharge capacity of $\sim 118( \pm 2) \mathrm{mAh} / \mathrm{g}_{\mathrm{LNMO}}$ with a first-cycle coulombic efficiency of $82 \%$ are observed, quite similar to the case without $\mathrm{VC}$ additive (see Table I). Thus, it is not surprising that after 108 cycles, the discharge capacity of $\sim 88( \pm 2) \mathrm{mAh} / \mathrm{g}_{\mathrm{LNMO}}$ is essentially identical to that of the VC-free electrolyte, even though the coulombic efficiency up to cycle 30 is slightly lower (upper panel of Figure 4, orange points). The slightly larger difference between the $1 \mathrm{C} / 1 \mathrm{C}$ and the $1 \mathrm{C} / 3 \mathrm{C}$ discharge capacity suggests a somewhat higher cell resistance for the $0.17 \mathrm{wt} \%$ VC compared to the VC-free electrolyte, which we will correlate with the impedance data in the next section.

So far, the graphite/LNMO cell performance with VC-free electrolyte is clearly superior to VC-containing electrolyte. This observation, however, changes as the $\mathrm{VC}$ concentration is lowered to 0.09 wt $\%$ (Figure 4, red points), in which case we observe a higher $1^{\text {st }}$ cycle coulombic efficiency $(83 \%)$, an improved capacity retention $(95( \pm 2)$ $\mathrm{mAh} / \mathrm{g}_{\mathrm{LNMO}}$ after 108 cycles) compared to cells without $\mathrm{VC}$ additive $\left(88( \pm 1) \mathrm{mAh} / \mathrm{g}_{\mathrm{LNMO}}\right.$ after 108 cycles$)$, as well as a better coulombic efficiency reaching $99.7 \%$ (vs. $99.6 \%$ ) after 108 cycles.

As shown by Reaction 2a in Scheme 1, the oxidation of VC will release cations into the solution (presumably the cation radicals proposed in Reaction 2a) which will result in one or several of the following processes: i) electroneutrality in the electrolyte requires that lithium ions from the solution must intercalate into the graphite anode (under the reasonable assumption that no intercalation of the radical cations into graphite and/or the $\mathrm{PF}_{6}{ }^{-}$anions into LNMO can occur; this is a reasonable assumption, since the amount of C65 is small and as it is not fully graphitized), which would lead to a depletion of

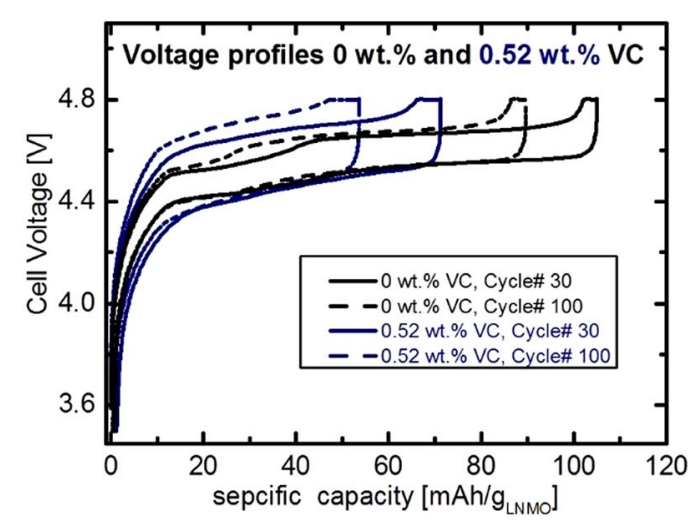

Figure 5. Full cell voltage profiles $\left(\mathrm{E}_{\mathrm{WE}}-\mathrm{E}_{\mathrm{CE}}\right)$ for cells with $0 \mathrm{wt} \%$ and 0.52 wt $\%$ VC in graphite/LNMO cells (cycled at $40^{\circ} \mathrm{C}$ ) after cycle 30 and cycle 100 .

lithium ions in the electrolyte; ii) if the released radical cations stabilize by the release of a proton (as evidenced in our previous study ${ }^{21}$ ), the proton concentration in the electrolyte would increase (simultaneously decreasing the lithium ion concentration), unless proton intercalation into graphite (during charge) and/or LNMO (during discharge) can occur to a significant degree; iii) VC oxidation and the formation of protons could lead to enhanced dissolution of transition metal ions (as this process is known to correlate with the electrolyte oxidation potential), ${ }^{37}$ which - together with oxidation products like HF themselves - could damage the SEI and lead to additional irreversible lithium loss at the anode; and, iv) VC oxidation could lead to impedance growth on anode and/or cathode due to reactions involving VC oxidation products. Regarding the latter, we will see in the following that while the observed impedance growth is substantial, it seems too low to explain the dramatic observed capacity fading. Figure 5 shows the full-cell voltage profiles $\left(\mathrm{E}_{\mathrm{WE}}-\mathrm{E}_{\mathrm{CE}}\right)$ for cells with $0 \mathrm{wt} \%$ and $0.52 \mathrm{wt} \% \mathrm{VC}$ after the $30^{\text {th }}$ and $100^{\text {th }}$ cycle. For cells containing $0 \mathrm{wt} \% \mathrm{VC}$ one can clearly see that the increase in the overpotential during cycling is minor (black solid line vs. black dotted line) and therefore the loss of active lithium is the most likely reason for the capacity fade. Cells with $0.52 \mathrm{wt} \% \mathrm{VC}$ show an increased polarization, which increases slightly during cycling (blue line vs. blue dotted line). However, as i) the capacity obtained during the constant voltage (CV) step does not increase significantly between cycle 30 and 100 for cells with $0.52 \mathrm{wt} \% \mathrm{VC}$, and ii) the voltage profiles for cells with $0.52 \mathrm{wt} \% \mathrm{VC}$ at the end of the of the constant-current charge still bend upwards, indicating that the cathode is close to complete delithiation, the capacity loss is most likely connected to a loss of active lithium and cannot be solely explained by an increased polarization.

Thus, we believe that the first two mechanisms are the most likely explanation for the observed rapid capacity fading of cells with high concentrations of $\mathrm{VC}$, even though it is currently unclear which one of these processes might be predominant: according to the first mechanism (i), lithium plating would eventually have to occur at the graphite anode and the lithium ion concentration in the electrolyte would get depleted due to a buildup of cationic oxidation products in the electrolyte; according to the second mechanism (ii), protons formed and accumulated in the electrolyte would be expected to corrode the LNMO cathode, resulting in transition metal dissolution and their

\begin{tabular}{|c|c|c|c|c|c|}
\hline Concentration & $0 \mathrm{wt} \% \mathrm{VC}$ & $0.09 \mathrm{wt} \% \mathrm{VC}$ & $0.17 \mathrm{wt} \% \mathrm{VC}$ & $0.52 \mathrm{wt} \% \mathrm{VC}$ & $2 \mathrm{wt} \% \mathrm{VC}$ \\
\hline
\end{tabular}



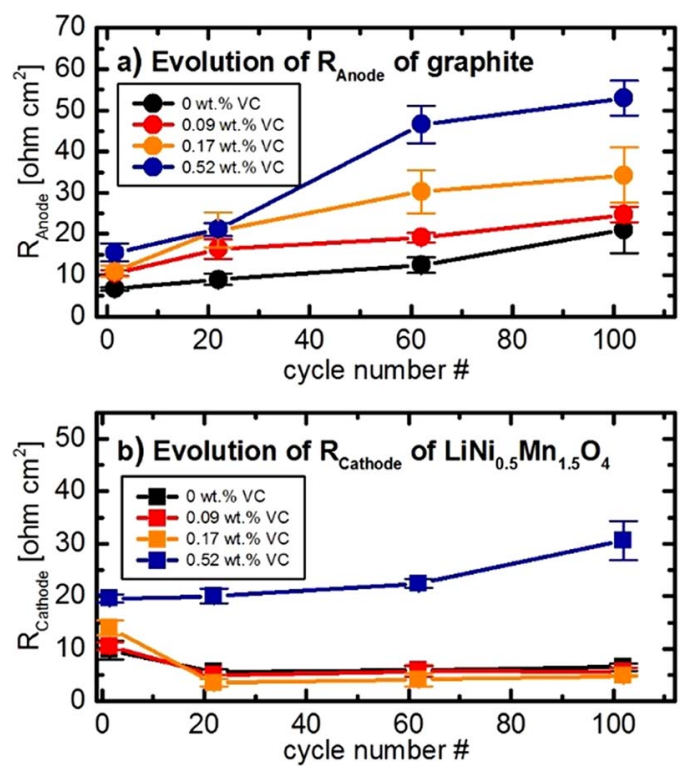

Figure 6. Evolution of the interfacial electrode resistances $\left(R_{\text {Anode }}\right.$ and $\mathrm{R}_{\text {Cathode }}$ ) of graphite/LNMO cells (measured with GWRE) over extended charge/discharge cycling at $1 \mathrm{C} / 1 \mathrm{C}$ and $40^{\circ} \mathrm{C}$ between 3.5 and $4.8 \mathrm{~V}$ in LP57 electrolyte with different $\mathrm{VC}$ concentrations. a) $\mathrm{R}_{\text {Anode }}$ of the graphite anode over cycling with $0 \mathrm{wt} \% \mathrm{VC}$ (black line), $0.09 \mathrm{wt} \% \mathrm{VC}$ (red line), $0.17 \mathrm{wt} \%$ $\mathrm{VC}$ (orange line), and $0.52 \mathrm{wt} \% \mathrm{VC}$ (blue line); b) $\mathrm{R}_{\text {Cathode }}$ of the LNMO cathode for the same electrolytes. Note that the impedance obtained after the first formation cycle at $25^{\circ} \mathrm{C}$ and $\mathrm{C} / 10$ at are included in this figure as cycle 1 (see data shown in Figure 3). Impedance spectra were recorded at 50\% SOC and $10^{\circ} \mathrm{C}$ from $100 \mathrm{kHz}$ to $100 \mathrm{mHz}$ with an amplitude of $0.6 \mathrm{~mA}$. Two cells were tested for each electrolyte composition; the data points show the average of the two cells, with error bars representing the standard deviation.

deposition on the graphite anode. Further studies are currently underway to prove/disprove these hypotheses.

Analysis of the impedance of anode and cathode during cycling.-In this section, we want to investigate the effect of different VC concentrations on the impedance of anode and cathode during cycling. Therefore, the T-cells with GWRE used for the examination of anode and cathode impedance vs. VC concentration after the first formation cycle at $25^{\circ} \mathrm{C}$ (data shown in Figure 3) were transferred to a $40^{\circ} \mathrm{C}$ climate chamber where they were was cycled at $1 \mathrm{C} / 1 \mathrm{C}$ charge/discharge, The cycling protocol was identical to that used for the cell cycling shown in Figure 4, except that the two 1C/3C charge/discharge cycles after every $20^{\text {th }}$ cycle were omitted. This, however, did not significantly alter the cycle-life: cells equipped with a GWRE and with VC-free electrolyte had a capacity of $87( \pm 2)$ $\mathrm{mAh} / \mathrm{g}_{\mathrm{LNMO}}$ after 102 cycles, which is comparable to a capacity of $89( \pm 1) \mathrm{mAh} / \mathrm{g}$ for the cells with the same electrolyte but without reference electrodes (see black symbols in Figure 4). Impedance was measured after the $22^{\text {nd }}, 62^{\text {nd }}$, and $102^{\text {nd }}$ cycle at $50 \%$ SOC and $10^{\circ} \mathrm{C}$.

Figures $6 \mathrm{a}$ and $6 \mathrm{~b}$ show the overall interfacial resistance of the graphite anode and the LNMO cathode versus cycle number. Note that the data from the first formation cycle are included, where cells were cycled at $25^{\circ} \mathrm{C}$.

The anode impedance (Figure 6a) increases roughly linearly with cycle number for cells without VC (black line) and those with 0.09 wt $\%$ (red line) and $0.17 \mathrm{wt} \% \mathrm{VC}$ additive (orange line). For cells with $0 \mathrm{wt} \% \mathrm{VC}$, the anode impedance increases from $\sim 7 \Omega \mathrm{cm}^{2}$ (first cycle) to $\sim 20 \Omega \mathrm{cm}^{2}\left(102^{\text {nd }}\right.$ cycle $)$. Cells containing $0.09 \mathrm{wt} \%$ and $0.17 \mathrm{wt} \% \mathrm{VC}$ show a similarly gradual impedance increase. For cells with a concentration of $0.17 \mathrm{wt} \% \mathrm{VC}$, the impedance increase is slightly higher compared to cells with $0.09 \mathrm{wt} \% \mathrm{VC}$, although the initial values for the anode impedance are identical $\left(\sim 10 \Omega \mathrm{cm}^{2}\right)$. The anode impedance of cells with $0.52 \mathrm{wt} \% \mathrm{VC}$ increases substantially during cycling, namely up to $\sim 55 \Omega \mathrm{cm}^{2}$ after the $102^{\text {nd }}$ cycle. An analogous increase of the graphite anode impedance with increasing VC concentrations was also observed by Burns et al. ${ }^{10}$ in commercialscale graphite/LCO cells for $>1 \mathrm{wt} \%$ VC. As will be discussed later, the difference in the $\mathrm{VC}$ threshold concentration is due to differences in the electrolyte to graphite surface ratio in commercial-scale vs. lab-scale cells.

Figure $6 \mathrm{~b}$ shows the interfacial resistance versus cycle number for the LNMO cathode. For cells with 0, 0.09, and $0.17 \mathrm{wt} \% \mathrm{VC}$, the impedance decreases after the formation cycle, reaching a constant value of $\sim 5 \Omega \mathrm{cm}^{2}$ after 20 cycles. In contrast, the LNMO cathode interfacial impedance starts out with a significantly higher value after the first formation cycle $\left(\sim 22 \Omega \mathrm{cm}^{2}\right)$ for the cells with $0.52 \mathrm{wt} \% \mathrm{VC}$ and increases with cycle number to $\sim 30 \Omega \mathrm{cm}^{2}$. We believe that the most likely explanation for the LNMO cathode impedance decrease for low $\mathrm{VC}$ concentrations is related to the different temperatures during the first formation cycle $\left(25^{\circ} \mathrm{C}\right)$ and the subsequent extended charge/discharge cycling $\left(40^{\circ} \mathrm{C}\right)$. During cycling at elevated temperatures, the electrolyte/LNMO interface initially formed at $25^{\circ} \mathrm{C} \mathrm{might}$ be restructured at $40^{\circ} \mathrm{C}$ by the enhanced solubility of some of the interfacial species (e.g., dissolution of organic interfacial species like poly $(\mathrm{VC})$ or of manganese fluoride produced by reaction with HF traces in the original electrolyte), leading to an impedance decrease. For the cells with $0.52 \% \mathrm{VC}$, one could imagine that the relatively high VC concentration has led to a thicker cathode surface film, which cannot be dissolved due to a change in temperature. Further, the ongoing cathode impedance growth during cycling could mean that not all VC has been consumed during the initial cycles.

It should be noted that if the content of conductive carbon in the LNMO electrodes is decreased from $5 \mathrm{wt} \%$ (used here) to $2 \mathrm{wt} \%$, an increase in LNMO cathode impedance during cycling can be observed even for low VC concentrations. This effect can clearly be attributed to a growing contact resistance at the current collector/electrode interface, as we will show in a future study. ${ }^{38}$ However, when $5 \%$ carbon black are added to the electrodes (see this study), the increase of the contact resistance is significant.

\section{Discussion}

In the following, we will seek to examine why the very low $\mathrm{VC}$ concentration of $0.09 \mathrm{wt} \%$ in our lab-scale graphite/LNMO cells leads to a clearly improved capacity retention (see Figure 5). This could be understood if these low concentrations of VC are sufficient to form a protective SEI, and if during the first formation cycle, VC reduction at the graphite anode can be completed prior to its oxidation at the LNMO cathode. We will also show that high VC concentrations result in significantly overcharge capacity in the first charging cycle, consistent with the oxidation of the majority of remaining $\mathrm{VC}$ at the LNMO cathode. Finally, based on the here observed effect of VC concentration on graphite/LNMO lab-scale cell performance, we will project the VC concentration levels in the electrolyte of commercialscale cells which would lead to an improved cycling performance of graphite/LNMO cells compared to VC-free electrolyte.

Estimated coverage of VC derived SEI on graphite surface with 0.09 wt\% VC additive. - In the following, we want to estimate how many monolayers of poly(VC) can be deposited on the graphite surface by the reduction of all $\mathrm{VC}$ contained in the electrolyte with 0.09 wt $\%$ VC, i.e., for the concentration which showed the best capacity retention in Figure 4. The purpose of this estimate is to evaluate whether the amount of VC-derived SEI (consisting largely of poly(VC)) at this low $\mathrm{VC}$ concentration could yield monolayer thick films, which would be required for surface passivation.

First, we approximate the surface area that can be occupied by one repeat unit of poly(VC), corresponding to the reductive decomposition of one VC molecule. ${ }^{39}$ Analogous to Jung et al., ${ }^{18}$ we assume that one adsorbed decomposition product of VC consists of eight atoms (total amount of atoms per poly(VC) repeat unit) and that every atom occupies a square with an average length of a carbon-carbon single 
bond of $0.15 \mathrm{~nm}$. Thus, the corresponding area that would be covered by one poly $(\mathrm{VC})$ unit equals to $8 \times\left(0.15 \mathrm{~nm}^{2}\right)^{2}=0.18 \mathrm{~nm}^{2}$. Taking into account the Avogadro constant $\left(\mathrm{N}_{\mathrm{A}}=6.022 \cdot 10^{23}\right.$ atoms $\left./ \mathrm{mol}\right)$ and the total surface area of the graphite anodes used in this study $\left(0.033 \mathrm{~m}^{2}\right.$ Graphite, based on a BET surface area of $\sim 5 \mathrm{~m}^{2} / \mathrm{g}$, a loading of $\sim 7 \mathrm{mg}_{\text {Graphite }} / \mathrm{cm}^{2}$ electrode, and a geometric surface area of $0.95 \mathrm{~cm}^{2}$ ), we can now estimate how many moles of $\mathrm{VC}$ are required to form one monolayer $n_{\mathrm{ML}}$ of poly(VC) on the graphite surface:

$$
n_{\mathrm{ML}}=\frac{0.033 \mathrm{~m}^{2}}{\mathrm{~N}_{\mathrm{A}} \times 0.18 \mathrm{~nm}^{2}}=0.307 \mu \mathrm{mol} / \mathrm{ML}
$$

To obtain the effective number of monolayers of poly(VC) produced on the graphite anode during the first formation cycles, one would need to estimate the fraction of the added moles of VC which are reduced at the anode compared to the fraction which might be oxidized at the cathode. Based on the impedance data in Figure 3b, the LNMO impedance after formation increases only in the cases where the $\mathrm{VC}$ concentration is $\geq 0.17 \mathrm{wt} \%$, so that it is reasonable to assume that for cells with $0.09 \mathrm{wt} \% \mathrm{VC}$, all $\mathrm{VC}$ in the electrolyte is only reduced at the anode, since the oxidation of excess $\mathrm{VC}$ on the cathode obviously leads to a highly resistive film (presumably also poly $(\mathrm{VC})^{17}$ ) on the LNMO cathode. Hence, it should be a reasonable estimate that the total amount of $\mathrm{VC}$ in the $0.09 \mathrm{wt} \% \mathrm{VC}$ electrolyte $\left(n_{\mathrm{VC}}=0.73 \mu\right.$ mol $_{\mathrm{VC}}$ in $60 \mu \mathrm{L}$ electrolyte $)$ will be reduced at the anode within the first formation cycle to form an SEI layer. In this case, the total number of deposited poly (VC) monolayers $N_{\mathrm{ML}}$ in the anode SEI can be estimated as:

$$
N_{\mathrm{ML}}=\frac{n_{\mathrm{VC}}}{n_{\mathrm{ML}}}=\frac{0.73 \mu \mathrm{mol}_{\mathrm{VC}}}{0.307 \mu \mathrm{mol} / \mathrm{ML}}=2.4 \mathrm{ML}
$$

The resulting value on the order of 2-3 monolayer equivalents of poly(VC) could in principle be sufficient to build a passivating VC-derived SEI on the graphite anode. The thickness of this layer, $d_{S E I}$, can be estimated by assuming that the average monolayer thickness $d_{\mathrm{ML}}$ will roughly be the length of a carbon-carbon single bond $(0.15 \mathrm{~nm})$ :

$$
d_{\mathrm{SEI}}=N_{\mathrm{ML}} \times d_{\mathrm{ML}}=2.4 \mathrm{ML} \times 0.15 \mathrm{~nm} / \mathrm{ML}=\sim 0.4 \mathrm{~nm}
$$

In view of the superior cycling performance with $0.09 \mathrm{wt} \% \mathrm{VC}$ compared to VC-free electrolyte or electrolyte with higher VC concentrations (see Figure 4) and considering the above estimates, we can finally conclude that a VC concentration of $0.09 \mathrm{wt} \%$ is on the one hand sufficiently small to be completely reduced within the first cycle, thus avoiding any detrimental side reactions during subsequent oxidation at the LNMO cathode, and on the other hand still large enough to accomplish adequate passivation of the graphite anode with an average SEI thickness of $\sim 0.4 \mathrm{~nm}$. The overall SEI will be thicker than $\sim 0.4 \mathrm{~nm}$ as also EC and the $\mathrm{PF}_{6}{ }^{-}$anion can be reduced after the initial cycles, however a sufficient fraction of the SEI consists of poly(VC) leading to enhanced stability.

Reduction and oxidation of VC considering the half-cell potentials of graphite and LNMO.-The above analysis tacitly assumed that the quantity of $\mathrm{VC}$ in the $0.09 \mathrm{wt} \%$ electrolyte can be reduced at the graphite anode prior to the onset of VC oxidation at the LNMO cathode during the first formation cycle. That this is indeed feasible can be shown by examining the graphite and LNMO half-cell potentials during the first charging of graphite/LNMO cells. To follow the half-cell potentials during the first charge, a graphite/LNMO cell with $0 \mathrm{wt} \% \mathrm{VC}$ and a lithium metal reference electrode was used. Figure 7 shows the potential of the graphite anode vs. $\mathrm{Li} / \mathrm{Li}^{+}$and of the LNMO cathode vs. $\mathrm{Li} / \mathrm{Li}^{+}$during the first part of the formation (up to a first charge capacity of $13 \mathrm{mAh} / \mathrm{g}_{\mathrm{LNMO}}$, which correspond to $\sim 1 \mathrm{~h}$ of charge at $\mathrm{C} / 10)$. The dark blue line represents the graphite half-cell potential, while the vertical dashed lines indicate the onset for the VC reduction at $\sim 1.8 \mathrm{~V}$ vs. $\mathrm{Li} / \mathrm{Li}$ (blue line) and the reduction of $\mathrm{EC}$ at $\sim 0.8 \mathrm{~V}$ vs. $\mathrm{Li} / \mathrm{Li}^{+}$(red line) taken from References 4 and 5 . After a charge capacity of only $\sim 0.5 \mathrm{mAh} / \mathrm{g}_{\mathrm{LNMO}}(\sim 2$ minutes at $\mathrm{C} / 10)$, the onset potential for the reduction of $\mathrm{VC}$ is reached, whereas after a

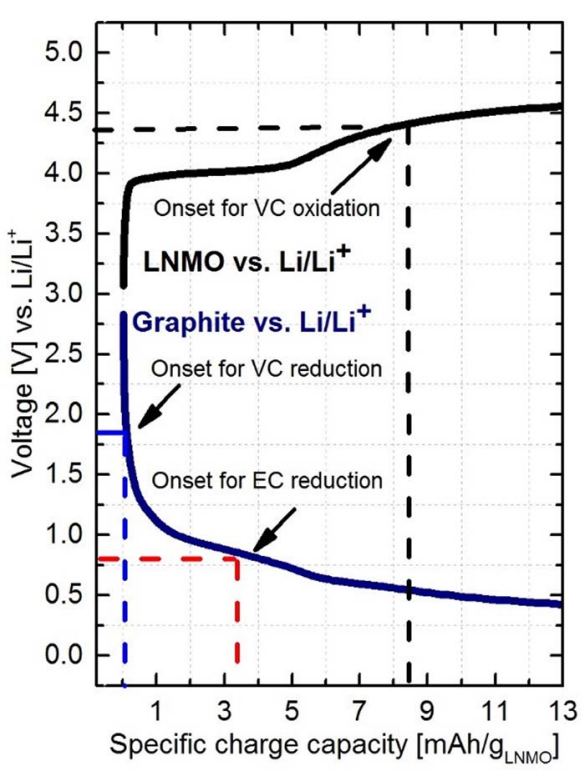

Figure 7. Half-cell potentials of LNMO (black line) and graphite (blue line) vs. $\mathrm{Li} / \mathrm{Li}^{+}$during the first formation cycle at $\mathrm{C} / 10$ and $25^{\circ} \mathrm{C}$ in an $\mathrm{VC}$-free LP57 electrolyte. The vertical dashed lines mark the onset potentials for VC reduction (blue), EC reduction (red), and VC oxidation (black).

total capacity of $\sim 4.5 \mathrm{mAh} / \mathrm{g}_{\mathrm{LNMO}}(\sim 18$ minutes at $\mathrm{C} / 10)$, the onset potential for EC reduction is reached. At the same time, the half-cell potential of the LNMO cathode (Figure 7, black line) shows a short plateau around $\sim 4.0 \mathrm{~V}$ vs. $\mathrm{Li} / \mathrm{Li}^{+}$for $\sim 6 \mathrm{mAh} / \mathrm{g}_{\mathrm{LNMO}}$, corresponding to the $\mathrm{Mn}^{3+} / \mathrm{Mn}^{4+}$ redox couple. Upon further charging, the LNMO potential gradually increases toward its main voltage plateau at $\sim 4.7 \mathrm{~V}$ vs. $\mathrm{Li} / \mathrm{Li}^{+}$, which belongs to the $\mathrm{Ni}^{2+} / \mathrm{Ni}^{3+}$ redox couple (due to the zoomed-in view of the capacity axis, only the onset for the plateau at $4.7 \mathrm{~V}$ vs. $\mathrm{Li} / \mathrm{Li}^{+}$is visible) ${ }^{40}$ An potential of $\sim 4.3 \mathrm{~V} \mathrm{vs.} \mathrm{Li} / \mathrm{Li}^{+}$, which corresponds to the onset potential for VC oxidation (black vertical line), is reached by the LNMO cathode after $\sim 8.5 \mathrm{mAh} / \mathrm{g}_{\mathrm{LNMO}}$ (i.e., $~ 34$ minutes) in this first charge of the graphite/LNMO cell. This means that there are $\sim 8 \mathrm{mAh} / \mathrm{g}_{\text {LNMO }}$ or $\sim 30$ minutes during the first charge where the graphite potential is already low enough to reduce $\mathrm{VC}$, but where the LNMO potential is still too low to oxidize VC (illustrated by the difference between the vertical blue and black lines in Figure 6 ). The capacity of $\sim 8 \mathrm{mAh} / \mathrm{g}_{\mathrm{LNMO}}$ can now be compared to the theoretical capacities required for the reduction of different amounts of VC in the electrolyte.

Based on a previous study, ${ }^{5}$ the first step in the formation of poly(VC) is most likely the one-electron reduction of $\mathrm{VC}$ to the radical anions $\bullet \mathrm{CH}=\mathrm{CH}-\mathrm{O}-\mathrm{COO}^{-}$or $\bullet \mathrm{CH}=\mathrm{CH}-\mathrm{O}^{-}$(upon release of $\mathrm{CO}_{2}$ ), both of which can react with $\mathrm{VC}$ to poly(VC). Thus, the formation of poly(VC) would require $\leq 0.5$ electrons per $\mathrm{VC}$ molecule (depending on the number of repeat units in the poly(VC) product). This implies that the reduction of $0.73 \mu \mathrm{mol} \mathrm{VC}$ in the $0.09 \mathrm{wt} \%$ $\mathrm{VC}$ electrolyte would require a reductive charge of $\leq 0.010 \mathrm{mAh}$ or, if referenced to the mass of LNMO in the cell $(12.9 \mathrm{mg}$, based on a loading of $13.6 \mathrm{mg}_{\mathrm{LNMO}} / \mathrm{cm}^{2}$ and an electrode area of $0.95 \mathrm{~cm}^{2}$ ), a charge of $\leq 0.76 \mathrm{mAh} / \mathrm{g}_{\mathrm{LNMO}}$. Thus, for the $0.09 \mathrm{wt} \% \mathrm{VC}$ electrolyte, the total amount of $\mathrm{VC}$ in the electrolyte can easily be reduced at the graphite anode before the LNMO cathode potential reaches the onset potential for VC oxidation (which occurs at $\sim 8 \mathrm{mAh} / \mathrm{g}_{\mathrm{LNMO}}$ after the $\mathrm{VC}$ reduction onset, as discussed before). The same analysis would suggest that even for our $\mathrm{VC}$ concentration of $0.52 \mathrm{wt} \%$, the required reductive charge of $\leq 4.5 \mathrm{mAh} / \mathrm{g}_{\mathrm{LNMO}}$ would still be available prior to reaching an LNMO potential of $\sim 4.3 \mathrm{~V}$, which is required to oxidize $\mathrm{VC}$; on the other hand, for $2 \mathrm{wt} \% \mathrm{VC}$, the reductive charge which can be passed before the LNMO cathode reaches $\sim 4.3 \mathrm{~V}$ would likely not suffice to reduce all of the $\mathrm{VC}$ in the electrolyte (which would require 
$\left.\leq 17.3 \mathrm{mAh} / \mathrm{g}_{\mathrm{LNMO}}\right)$. While these estimates show that even $0.52 \mathrm{wt} \%$ $\mathrm{VC}$ in our electrolyte could in principle be reduced at the graphite anode before the LNMO cathode potential is high enough to oxidize $\mathrm{VC}$, the LNMO cathode impedance data after the first formation cycle (see Figure $3 b$ ) clearly shows a substantial LNMO impedance increase with $\mathrm{VC}$ concentrations $\geq 0.17 \mathrm{wt} \%$, indicating that there is residual VC left in cells with $\geq 0.17 \mathrm{wt} \%$ VC after the initial 8.5 $\mathrm{mAh} / \mathrm{g}_{\mathrm{LNMO}}$ charge. These observations fit well to a study by Petibon et al., ${ }^{11}$ who showed that in commercial-scale NMC/graphite pouch cells with $1 \%$ wt.VC (corresponding to $0.09 \mathrm{wt} \% \mathrm{VC}$ in our cells in terms of VC to graphite surface ratio), more than $80 \%$ of the initial $\mathrm{VC}$ is already consumed after $\sim 50 \%$ of the first charge, whereas at the same point, about $4.2 \mathrm{wt} \% \mathrm{VC}$ is left if the cell originally contained 6 wt $\%$ VC (i.e., $0.52 \mathrm{wt} \% \mathrm{VC}$ in our study). Our results suggest that for the formation of a passivating anode SEI, VC concentrations between $0.09 \mathrm{wt} \%$ (no LNMO impedance increase compared to $0 \mathrm{wt} \% \mathrm{VC}$, see Figure $3 b$ ) and 0.17 wt\% (LNMO impedance increase, see Figure $3 \mathrm{~b})$ are sufficient. Assuming that the reduction of VC is substantially slowed down once this passivation has been reached, any excess VC would be oxidized at the LNMO cathode once it exceeds a potential of $\sim 4.3 \mathrm{~V}$, as seen in the LNMO impedance for cells with $\geq 0.17 \mathrm{wt} \%$ VC.

Overcharge capacities from the anodic decomposition of $V C$.The impedance data in Figure $3 \mathrm{~b}$ suggest that in the case of higher VC concentrations ( $\geq 0.17 \mathrm{wt} \%)$, a significant fraction of the VC present in the electrolyte must be oxidized in the first cycle at the LNMO cathode. In this case, the additional oxidative current used for the oxidation of VC should increase the first cycle charge capacity. ${ }^{16,17}$ Therefore, we want to analyze the first cycle overcharge capacities in graphite/LNMO cells with different amounts of VC. The formation protocol consists of two $\mathrm{C} / 10$ charge $(\mathrm{CCCV}) /$ discharge $(\mathrm{CC})$ cycles between $3.5 \mathrm{~V}-4.8 \mathrm{~V}$ cell voltage with a current limit of $\mathrm{C} / 20$ for the CV step. Figure 8a shows the first charge of cells with different $\mathrm{VC}$ concentrations. For the cells with a concentration of $0 \mathrm{wt} \% \mathrm{VC}$
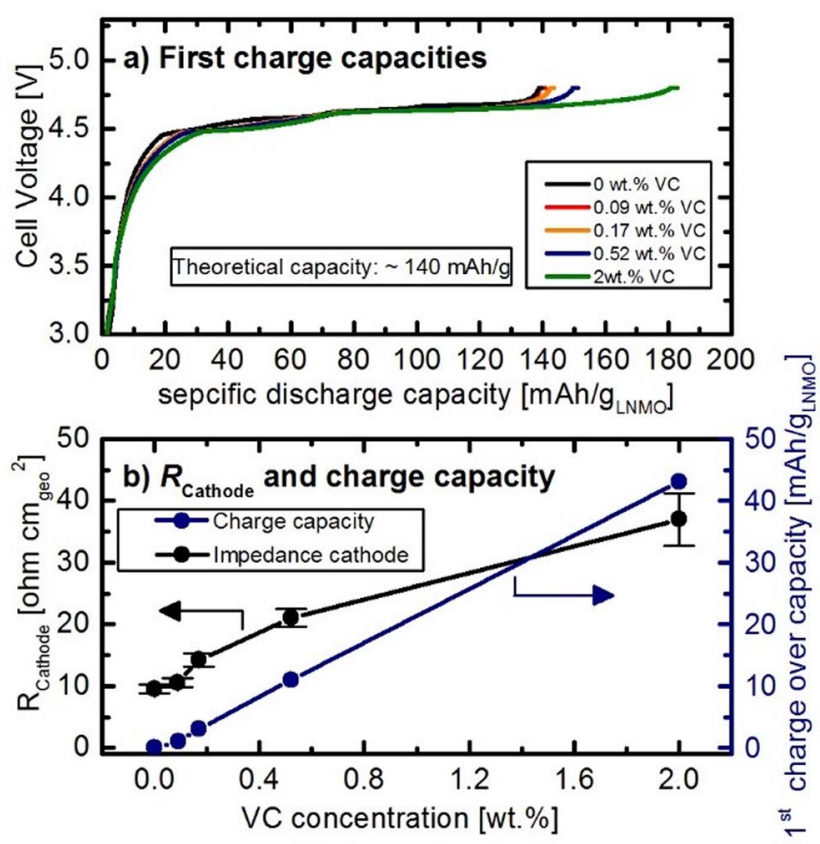

Figure 8. a) First charge of graphite/LNMO cells with $0 \mathrm{wt} \% \mathrm{VC}$ (black line), $0.09 \mathrm{wt} \% \mathrm{VC}$ (red line), $0.17 \mathrm{wt} \% \mathrm{VC}$ (orange line), $0.52 \mathrm{wt} \% \mathrm{VC}$ (blue line), and $2 \mathrm{wt} \% \mathrm{VC}$ (green line). The charge is carried out in a constant current constant charge mode (CCCV) with a current limit of $\mathrm{C} / 20$ for the $\mathrm{CV}$ step. b) First charge capacities of the graphite/LNMO cell and LNMO cathode interfacial impedance, $\mathrm{R}_{\text {Cathode }}$, after first charge/discharge (data from Figure $3 b)$ vs. VC concentration. and $0.09 \mathrm{wt} \% \mathrm{VC}$, the first charge capacities are $\sim 140 \mathrm{mAh} / \mathrm{g}_{\mathrm{LNMO}}$ and $\sim 141 \mathrm{mAh} / \mathrm{g}_{\mathrm{LNMO}}$ (black line and red line in Figure $8 \mathrm{a}$ ). These values correspond to the theoretical capacity of the LNMO electrode, consistent with our above assumption that no VC oxidation occurs in cells with $0.09 \mathrm{wt} \% \mathrm{VC}$. When the concentration of $\mathrm{VC}$ is increased to $0.17 \mathrm{wt} \% \mathrm{VC}$, the capacity increases to $\sim 144 \mathrm{mAh} / \mathrm{g}_{\mathrm{LNMO}}$ (yellow line in Figure 8a), indicating that the now occurring electrochemical oxidation of VC causes an additional charge capacity. This is further supported when the concentrations of $0.52 \mathrm{wt} \%$ and $2 \mathrm{wt} \%$ are taken into account, for which the first charge capacity increases to $\sim 151 \mathrm{mAh} / \mathrm{g}_{\mathrm{LNMO}}$ and to $\sim 183 \mathrm{mAh} / \mathrm{g}_{\mathrm{LNMO}}$, respectively (see blue line and green line in Figure 8a).

In the following, we want to correlate the overcharge capacities arising from $\mathrm{VC}$ oxidation (i.e., the first charge capacity minus $140 \mathrm{mAh} / \mathrm{g}_{\mathrm{LNMO}}$, which is the first charge capacity of a cell with VCfree electrolyte) to the impedance of the LNMO electrode. In Figure $8 \mathrm{~b}$, the first charge capacities (blue symbols, right y-axis) are plotted vs. VC concentration. It is apparent that for VC concentrations $\geq 0.17 \mathrm{wt} \%$, the charge capacity increases proportionally with the $\mathrm{VC}$ concentration (i.e., doubling the $\mathrm{VC}$ concentration leads to a doubling of the overcharge capacity), which is a clear evidence that excess VC is being oxidized quantitatively during the first charge. The lower than predicted overcharge for the cells with $0.09 \mathrm{wt} \% \mathrm{VC}$ is in agreement with our assumption that in cells with $0.09 \mathrm{wt} \% \mathrm{VC}$, nearly all $\mathrm{VC}$ is consumed at the anode before its oxidation can occur. This overall trend fits very well with the LNMO impedance data obtained after the first cycle (see Figure 3b), which are re-plotted in Figure 8b (black symbols, left y-axis), demonstrating that the overcharge capacity and the impedance of the LNMO cathode are correlated. As mentioned before, the impedance increase at the positive electrode can be explained by the formation of poly(VC), which can also be formed during oxidation (see reactions $2 \mathrm{a}$ and $2 \mathrm{~b}$ in Scheme 1 ). In contrast to the first charge capacity, the cathode impedance grows less severely at high VC concentrations. An explanation for this behavior could be the structural or morphological changes in the poly(VC) layer once a certain thickness has been reached, which might affect the cathode impedance.

The slope of the overcharge capacity vs. VC concentration (see blue line in Figure 8a) corresponds to $\sim 2.4$ electrons per VC molecule. However, so far only a $\leq 1$ electron per oxidized VC molecule has been proposed (see reactions $2 \mathrm{a}$ and $2 \mathrm{~b}$ in Scheme 1). ${ }^{17}$ We thus propose that the larger number of electrons per VC could arise from a further oxidation of the initially produced radical cation (see reaction $2 \mathrm{a}$ in Scheme 2), following its stabilization through the release of a proton (see reaction 2c, Scheme 2). The analogous formation of protons during the oxidation of EC/EMC electrolyte has been proposed by Metzger et al., ${ }^{21}$ based on the observation that $\mathrm{H}_{2}$ is evolved on the

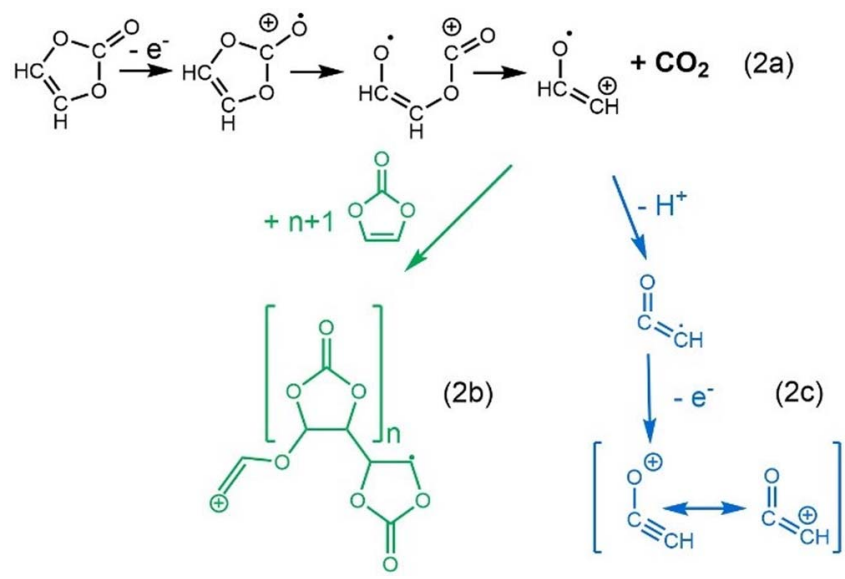

Scheme 2. Extension of the VC oxidation mechanism from Scheme 1 including proton abstraction and a second oxidation step. 
anode during electrolyte oxidation, presumably due to the reduction of released protons. After the release of a proton, the intermediate could then be oxidized again, resulting in a mesomerically stabilized cation. Further, this end product of path $2 \mathrm{c}$ could again abstract a proton, which would lead to the formation of dicarbon monoxide, a very reactive gas. The so far unexplained 0.4 electrons per molecule VC could be explained by a crosstalk mechanism: oxidation products can diffuse to the anode, where they will be reduced and can then again be oxidized at the cathode, leading to an apparently higher number of electrons per VC. Besides, it is possible that also poly(VC) can be oxidized at high potentials, most likely leading to proton abstraction and additional crosslinking.

Dependence of the graphite anode impedance on the positive electrode (LNMO vs. LFP).—As a next step, we want to understand how the positive electrode affects the impedance of the graphite anode. Therefore, the data of this study is compared with our previous study, ${ }^{13}$ where we have investigated the effect of different VC concentrations $(0.17 \mathrm{wt} \% \mathrm{VC}$ and $0.52 \mathrm{wt} \% \mathrm{VC})$ on the impedance in graphite/LFP cells. As the upper cutoff potential of the LFP cathode is $\sim 4.1 \mathrm{~V}$ vs. $\mathrm{Li} / \mathrm{Li}^{+}$(compared to $\sim 4.9 \mathrm{~V} \mathrm{vs.} \mathrm{Li} / \mathrm{Li}^{+}$for LNMO), the oxidative decomposition of VC does not occur in graphite/LFP cells, which is in accordance with the LFP cathode impedance being independent from VC concentration (see Figure 8 in Reference 13). To compare the anode impedance data of the graphite/LFP cells from our previous study ${ }^{13}$ and the graphite/LNMO cells from the present work, we recalculate the $\mathrm{VC}$ concentrations used for both cell chemistries in units of $\mathrm{mg}_{\mathrm{VC}} / \mathrm{m}^{2}$ Graphite.

Figure 9 shows graphite anode impedances $\left(R_{\text {Anode }}\right)$ after the first formation cycle in graphite/LNMO cells (black symbols; data from Figure 3a) and those in graphite/LFP cells (red symbols) vs. the VC concentration in $\mathrm{mg} \mathrm{v}_{\mathrm{V}} / \mathrm{m}^{2}$ Graphite. As one would expect, the graphite anode impedances for cells with $0 \mathrm{wt} \% \mathrm{VC}$ are very similar, with a value of $\sim 7 \Omega \mathrm{cm}^{2}$ for the graphite/LNMO cells and $\sim 5 \Omega \mathrm{cm}^{2}$ for the graphite/LFP cells. When VC is added to the graphite/LFP cells, the graphite anode impedances increases linearly with $\mathrm{VC}$ concentration (to $\sim 16$ and $\sim 47 \Omega \mathrm{cm}^{2}$ for 0.17 and $0.52 \mathrm{wt} \% \mathrm{VC}$, respectively), as described previously. ${ }^{13}$ Interestingly, the increase of anode impedance between $0 \mathrm{wt} \%$ and $0.09 \mathrm{wt} \% \mathrm{VC}$ in graphite/LNMO cells matches precisely to the linear slope of the graphite/LFP cells. However, at VC concentrations $\geq 0.17 \mathrm{wt} \%$, a deviation from the linear trend is

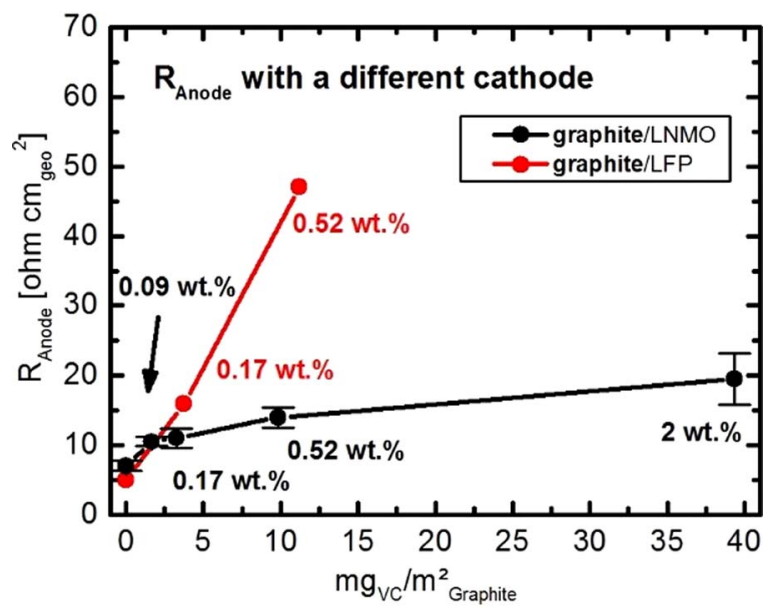

Figure 9. Interfacial resistance of graphite anodes after formation at $25^{\circ} \mathrm{C}$ in graphite/LNMO cells (this study) compared to graphite anodes in graphite/LFP cells from our earlier study. ${ }^{13}$ The VC concentration is recalculated in units of $\mathrm{mg} \mathrm{VC}_{\mathrm{V}} / \mathrm{m}^{2}$ Graphite to assess for the slightly different areal loadings (namely $\sim 2.6 \mathrm{mAh} / \mathrm{cm}^{2}$ geo in the graphite/LNMO cells and $\sim 2.2 \mathrm{mAh} / \mathrm{cm}^{2}$ geo in the graphite/LFP cells, based on $340 \mathrm{mAh} / \mathrm{g}_{\text {graphite }}$ ). The error bars represent the standard deviation between two measurements. All corresponding impedance spectra were recorded at $10^{\circ} \mathrm{C}$ from $100 \mathrm{kHz}$ to $100 \mathrm{mHz}$. observed for graphite/LNMO cells (to $\sim 10$ and $\sim 14 \Omega \mathrm{cm}^{2}$ for 0.17 and $0.52 \mathrm{wt} \% \mathrm{VC}$, respectively), i.e., the graphite anode impedance at high VC concentrations is much lower for graphite/LNMO compared to graphite/LFP cells. This effect can be explained by considering the competing reactions at the respective cathode: In graphite/LFP cells, no VC is consumed by the cathode, and the only reaction to occur is the reductive polymerization of $\mathrm{VC}$ on the anode, whereas the oxidation of $\mathrm{VC}$ on the cathode competes with its reduction in graphite/LNMO cells. Hence, less VC is available for reduction, leading to a lower anode impedance at similar $\mathrm{mg} \mathrm{v}_{\mathrm{V}} / \mathrm{m}^{2}$ Graphite amounts. At this point, we would like to mention that the formation of the graphite/LFP cells was carried out at $40^{\circ} \mathrm{C}$, while the graphite/LNMO cells were formed at $25^{\circ} \mathrm{C}$, which might also affect the resulting anode impedance (measured at $10^{\circ} \mathrm{C}$ in both cases); however, as the anode impedance for 0 wt $\%$ VC is identical for both cell chemistries, and the graphite/LNMO anode impedance with $0.09 \mathrm{wt} \% \mathrm{VC}$ fits well to the linear relationship between $\mathrm{VC}$ concentration and anode impedance in graphite/LFP cells, we believe that the oxidation of VC at the cathode is the major cause for the observed differences between graphite/LNMO and graphite/LFP cells.

Projected performance of graphite/LNMO commercial-scale cells.-The present study clearly proves that VC can enhance the cycling stability of graphite/LNMO cells, in contrast to previous reports. Yet, it also demonstrates that the concentration of $\mathrm{VC}$ in graphite/LNMO cells has to be carefully tuned, as the oxidation of only low amounts of VC can already lead to a deterioration of the capacity retention. The optimal $\mathrm{VC}$ concentration, corresponding to the amount of $\mathrm{VC}$ that can be reduced before the cathode reaches a potential $>4.2 \mathrm{~V}$ vs. $\mathrm{Li} / \mathrm{Li}^{+}$, depends on the ratio of electrolyte to graphite surface area as well as the formation procedure (i.e., the time at potentials where $\mathrm{VC}$ reduction, but no oxidation can occur). In our case, the best performance in lab-scale cells is achieved with a concentration of $0.09 \mathrm{wt} \% \mathrm{VC}$, which corresponds to $\sim 1 \mathrm{wt} \% \mathrm{VC}$ in commercial-scale cells as used by Dahn's group (for details on this conversion please refer to Ref. 13). While Burns et al. ${ }^{7}$ have shown that already $1 \mathrm{wt} \%$ VC leads to a significantly better capacity retention in commercial-scale graphite/LCO and graphite/NMC cells, the cycle life of commercial-scale graphite/NMC cells depends strongly on the amount of VC available. ${ }^{10}$ Hence, $1 \mathrm{wt} \% \mathrm{VC}$ by its own might not be sufficient to achieve an outstanding cycling performance with graphite/LNMO cells. Therefore, a combination of $1 \mathrm{wt} \% \mathrm{VC}$ with other additives, which are either oxidatively stable or whose oxidation products are not detrimental to cell performance, and which can act as "repair additives" for the VC-derived SEI, would be a feasible combination for commercial-scale graphite/LNMO cells. To assure that diffusion of VC in a lab-scale cell is not the limiting factor when these type of cells are compared to commercial-scale cells we estimate the diffusion times for these two cell types: The diffusion time can be estimated as follows:

$$
t=\frac{(\mathrm{x} \cdot \tau)^{2}}{D}
$$

where $t$ is the characteristic diffusion time, $x$ is the length of the diffusion path, $\tau$ is the tortuosity of the separator, and $D$ is the diffusion coefficient. A typical value for the liquid diffusion is in the order of $10^{-6} \mathrm{~cm}^{2} / \mathrm{s}$ (J. Landesfeind et al. ${ }^{40}$ ). In our lab test cells, two glass fiber separators have been used $(x \approx 2 \cdot 200 \mu \mathrm{m}, \tau \approx 1)$, yielding a diffusion time on the order of:

$$
t=\frac{(400 \mu \mathrm{m})^{2}}{10^{-6} \frac{\mathrm{cm}^{2}}{\mathrm{~s}}}=1600 \mathrm{~s}
$$

In a commercial cell the distance between anode and cathode is $\sim 25 \mu \mathrm{m}$ with an average tortuosity of $\tau \approx 4$ (see, e.g., J. Landesfeind et al. $^{41}$ ), yielding an approximate diffusion time constant of:

$$
t=\frac{(25 \mu \mathrm{m} \cdot 4)^{2}}{10^{-6} \frac{\mathrm{cm}^{2}}{\mathrm{~s}}}=100 \mathrm{~s}
$$


As the oxidation of $\mathrm{VC}$ would only become possible after $\approx 34$ minutes of charge, the rate of $\mathrm{VC}$ diffusion to the anode electrode is not limiting. During that initial time period, we believe that VC will be reduced preferentially at the anode, since its reduction potential is substantially higher than that of the EC and EMC solvents in LP57 $\left(\approx 1.7 \mathrm{~V}\right.$ vs. $\mathrm{Li} / \mathrm{Li}^{+}$for $\mathrm{VC}$ compared to $\approx 0.9 \mathrm{~V}$ for $\left.\mathrm{LP} 57\right){ }^{5}$

\section{Conclusions}

In this study, we use a combined on-line electrochemical mass spectrometry (OEMS) and impedance analysis with a micro-reference electrode (GWRE), in order to i) understand the oxidative (in-)stability of the additive vinylene carbonate (VC), and, ii) to investigate the impact of the additive in graphite/ $\mathrm{LiNi}_{0.5} \mathrm{Mn}_{1.5} \mathrm{O}_{4}$ cells on the interfacial resistance of both anode and cathode. We have shown that the oxidation of $\mathrm{VC}$ occurs at an onset potential of $\sim 4.3 \mathrm{~V}$ vs. $\mathrm{Li} / \mathrm{Li}^{+}$(by OEMS), which leads to a significant impedance buildup on the LNMO cathode in graphite/LNMO cells. This was shown by monitoring the graphite anode and the LNMO cathode impedance after formation and during extended charge discharge cycling using a micro-reference electrode.

Based on these data, we could conclude that VC oxidation on the cathode is competing with VC reduction on the anode. During the initial charge of graphite/LNMO cells, a charge of $\sim 8 \mathrm{mAh} / \mathrm{g}_{\mathrm{LNMO}}$ can be passed before the LNMO cathode potential reaches $4.3 \mathrm{~V}$ vs. $\mathrm{Li} / \mathrm{Li}^{+}$while the anode potential is already low enough to reduce $\mathrm{VC}$ to form an anode SEI. As a consequence, if the total amount of $\mathrm{VC}$ in the electrolyte is high enough to form a passivating anode SEI during this initial part of the first charge, but low enough so that all VC is being consumed during the initial anode SEI formation, the capacity retention of cells with a VC-containing electrolyte is superior compared to VC-free electrolyte. In our lab-scale cells, this corresponds to the lowest tested VC concentration of $0.09 \mathrm{wt} \%$. Based on our previously discussed metrics for comparing additives in labscale vs. commercial-scale cells, this would translate into a $\sim 1 \mathrm{wt} \%$ VC concentration for commercial-scale cells.

\section{Acknowledgment}

Financial support by the BASF SE through its Network on Electrochemistry and Batteries is gratefully acknowledged. M. W. acknowledges funding by The German Federal Ministry for Economic Affairs and Energy (funding number 03ET6045D).

\section{References}

1. E. Peled, J. Electrochem. Soc., 126, 2047 (1979).

2. R. Imhof and P. Novák, J. Electrochem. Soc., 145, 3313 (1998).

3. M. Nie, D. Chalasani, D. P. Abraham, Y. Chen, A. Bose, and B. L. Lucht, J. Phys. Chem. C, 117, 1257 (2013).

4. H. Ota, Y. Sakata, A. Inoue, and S. Yamaguchi, J. Electrochem. Soc., 151, A1659 (2004).
5. B. Zhang, M. Metzger, S. Solchenbach, M. Payne, S. Meini, H. A. Gasteiger, A. Garsuch, and B. L. Lucht, J. Phys. Chem. C, 119, 11337 (2015).

6. M. Nie, J. Demeaux, B. T. Young, D. R. Heskett, Y. Chen, A. Bose, J. C. Woicik, and B. L. Lucht, J. Electrochem. Soc., 162, 7008 (2015).

7. J. C. Burns, N. N. Sinha, D. J. Coyle, G. Jain, C. M. VanElzen, W. M. Lamanna, A. Xiao, E. Scott, J. P. Gardner, and J. R. Dahn, J. Electrochem. Soc., 159, A85 (2012).

8. A. Würsig, H. Buqa, M. Holzapfel, F. Krumeich, and P. NovaF́k, Electrochem. Solid-State Lett., 8, A34 (2005).

9. L. El Ouatani, R. Dedryvère, C. Siret, P. Biensan, S. Reynaud, P. Iratcabal, and D. Gonbeau, J. Electrochem. Soc., 156, A103 (2009).

10. J. C. Burns, R. Petibon, K. J. Nelson, N. N. Sinha, A. Kassam, B. M. Way, and J. R. Dahn, J. Electrochem. Soc., 160, A1668 (2013).

11. R. Petibon, J. Xia, J. C. Burns, and J. R. Dahn, J. Electrochem. Soc., 161, A1618 (2014).

12. R. Petibon, J. Xia, L. Ma, M. K. G. Bauer, K. J. Nelson, and J. R. Dahn, J. Electrochem. Soc., 163, A2571 (2016).

13. S. Solchenbach, D. Pritzl, E. J. Y. Kong, J. Landesfeind, and H. A. Gasteiger, J. Electrochem. Soc., 163, A2265 (2016).

14. J. Hoffmann, M. Payne, and J. Li, ECS Meet. 224, Abstr, \#1106 (2013).

15. H. Lee, S. Choi, H. Kim, Y. Choi, S. Yoon, and J.-J. Cho, Electrochem. commun., 9 , 801 (2007).

16. Y.-M. Song, J.-G. Han, S. Park, K. Lee, and N.-S. Choi, J. Mater. Chem. A, 2, 9506 (2014).

17. Y. Dong, J. Demeaux, and B. L. Lucht, J. Electrochem. Soc., 163, A2413 (2016).

18. R. Jung, M. Metzger, D. Haering, S. Solchenbach, C. Marino, N. Tsiouvaras, C. Stinner, and H. A. Gasteiger, J. Electrochem. Soc., 163, A1705 (2016)

19. E. Markevich, G. Salitra, K. Fridman, R. Sharabi, G. Gershinsky, A. Garsuch, G. Semrau, M. Schmidt, and D. Aurbach, Langmuir, 30, 7414 (2014).

20. N. Tsiouvaras, S. Meini, I. Buchberger, and H. A. Gasteiger, J. Electrochem. Soc., 160, A471 (2013).

21. M. Metzger, B. Strehle, S. Solchenbach, and H. A. Gasteiger, J. Electrochem. Soc., 163, A798 (2016).

22. M. Metzger, C. Marino, J. Sicklinger, D. Haering, and H. A. Gasteiger, J. Electrochem. Soc., 162, A1123 (2015).

23. M. Klett, J. A. Gilbert, S. E. Trask, B. J. Polzin, A. N. Jansen, D. W. Dees, and D. P. Abraham, J. Electrochem. Soc., 163, A875 (2016).

24. R. Jung, M. Metzger, F. Maglia, C. Stinner, and H. A. Gasteiger, J. Electrochem. Soc., 164, A1361 (2017).

25. J. A. Seel and J. R. Dahn, J. Electrochem. Soc., 147, 892 (2000).

26. W. Märkle, N. Tran, D. Goers, M. E. Spahr, and P. Novák, Carbon., 47, 2727 (2009).

27. M. Metzger, J. Sicklinger, D. Haering, C. Kavakli, C. Stinner, C. Marino, and H. A. Gasteiger, J. Electrochem. Soc., 162, A1227 (2015).

28. M. Itagaki, N. Kobari, S. Yotsuda, K. Watanabe, S. Kinoshita, and M. Ue, J. Power Sources, 148, 78 (2005).

29. X. Zhang, J. K. Pugh, and P. N. Ross, J. Electrochem. Soc., 148, E183 (2001).

30. O. Borodin, W. Behl, and T. R. Jow, J. Phys. Chem. C, 117, 8661 (2013).

31. J. Self, C. P. Aiken, R. Petibon, and J. R. Dahn, J. Electrochem. Soc., 162, A796 (2015).

32. C. P. Aiken, J. Self, R. Petibon, X. Xia, J. M. Paulsen, and J. R. Dahn, J. Electrochem. Soc., 162, A760 (2015).

33. L. E. Downie, S. Hyatt, and J. R. Dahn, J. Electrochem. Soc., 163, A35 (2016).

34. L. Xing, W. Li, C. Wang, F. Gu, M. Xu, C. Tan, and J. Yi, J. Phys. Chem. B, 113, 16596 (2009).

35. T. Li, L. Xing, W. Li, Y. Wang, M. Xu, F. Gu, and S. Hu, J. Power Sources, 244, 668 (2013).

36. J. Landesfeind, D. Pritzl, and H. A. Gasteiger, J. Electrochem. Soc., 164, A1773 (2017).

37. D. H. Jang and S. M. Oh, J. Electrochem. Soc., 144, 3342 (1997).

38. D. Pritzl, A. Bumberger, M. Wetjen, S. Solchenbach, J. Landesfeind, and H. A. Gasteiger, Manuscr. prep.

39. A. L. Michan, B. S. Parimalam, M. Leskes, R. N. Kerber, T. Yoon, C. P. Grey, and B. L. Lucht, Chem. Mater, 28, 8149 (2016).

40. B. Li, L. Xing, M. Xu, H. Lin, and W. Li, Electrochem. commun., 34, 48 (2013).

41. A. Ehrl, J. Landesfeind, W. A. Wall, and H. A. Gasteiger, J. Electrochem. Soc., 164, A826 (2017). 